
\title{
Reseserch Suare \\ The Role of Institutional Quality in Health Expenditure-Labour Force Participation Nexus in Africa
}

\section{Olaide Sekinat Opeloyeru}

Department of Economics, College of Social and Management Sciences (COSMAS), Tai- Solarin University of Education ljagun, Ogun State, Nigeria

\section{Temitope Olanike Faronbi}

Department of Economics, Faculty of Economics and Management Sciences, University of Ibadan, Ibadan, Oyo State, Nigeria

Isiaka Akande Raifu ( $\boldsymbol{\nabla}$ heritagetiamiyu@gmail.com )

Department of Economics, Faculty of Economics and Management Sciences, University of Ibadan, Ibadan, Oyo State, Nigeria

\section{Method Article}

Keywords: Government Health Expenditure, Out-of-Pocket Health Expenditure, Labour Force Participation, Institutional Quality, Panel Fixed Effects, Two-Stage System GMM

Posted Date: September 27th, 2021

DOl: https://doi.org/10.21203/rs.3.rs-940235/v1

License: (c) (1) This work is licensed under a Creative Commons Attribution 4.0 International License. Read Full License 
The Role of Institutional Quality in Health Expenditure-Labour Force Participation Nexus in Africa

\begin{abstract}
The study investigated the role of institutional quality in the relationship between health expenditure and labour force participation (LFP) in Africa, taking into consideration two forms of health expenditures (government health expenditure (GHE) and out-of-pocket health expenditure (OOPHE)) and gender labour force participation dichotomy. We employed data of 39 African countries for the period between 2000 and 2018 using Panel Fixed Effects with Driscoll and Kraay standard errors and two-stage System Generalised Method of Moments (GMM). The results revealed that government health expenditure yields an increasing effect on total, female, and male LFP. OOPHE, in most cases, leads to a decline in LFP. The institutional quality was found to be detrimental to LFP. The magnitude of the positive effect of government health expenditure on LFP is reduced by the interaction of institutional quality with government expenditure. In conclusion, we advocate for the improvement in institutional apparatuses across African countries.
\end{abstract}

Keywords: Government Health Expenditure, Out-of-Pocket Health Expenditure, Labour Force Participation, Institutional Quality, Panel Fixed Effects, Two-Stage System GMM

JEI CODE: E62; H51; J21; O43 


\subsection{Introduction}

In a bid to achieve the Universal Health Coverage and to pursue the health goals for Sustainable Development Goals (SDGs), many health policymakers in Africa have seen health expenditure as one of the germane components of health outcomes. At the 2001 Abuja Declaration, African leaders agreed to allocate at least $15 \%$ of their yearly budget to the health sector to improve, promote and foster quality healthcare in their countries but many of these countries are defaulters of this declaration. For instance, the average total health spending ranges from $5 \%$ to $6 \%$ of the Gross Domestic Product (GDP) between the years 2000 and 2015. However, the per capita total expenditure increased from $\$ 150$ to $\$ 292$ based on 2015 purchasing power parity (PPP) with variations across different countries in Africa. Available statistics shows that, on average, per capita health expenditure in low-income African countries stood at $\$ 99$, ranging from $\$ 23$ in Central African Republic to \$256 in Sierra Leone. Middle-income African countries recorded a mean per capita health expenditure of $\$ 298$, ranging from $\$ 147$ in Djibouti to $\$ 774$ in Tunisia. The upper-middle income African countries have an average per capita income of $\$ 914$ with a minimum of $\$ 481$ for Gabon and maximum of $\$ 1,100$ for Mauritius (World Bank Development Indicator, 2020).

Unlike the rest of the world which has an average of $22 \%$ of the total health expenditure as out of pocket payments, African countries are over-reliance on out-of-pocket health expenditure (hereafter, OOPHE). The average OOPHE in Africa stood at $36 \%$ of total health expenditure. The phenomenon borne out of paucity of government health facilities. The paucity of healthcare facilities has denied the majority of the African citizens the access to quality healthcare. The obvious consequence is the lower health outcomes. The situation may not give majority of the ability to participate in labour market. This is because it takes a physically healthier individual to energetically participate in the labour market. Grossman (1972) and Bloom and Canning (2000; 2003) asserted that being healthy will not only be of benefit to the individual in non-labour market activities but will affect the entire economy through labour market activities. Thus, the combined effect of low government spending on health and heavy dependence on out-of-pocket payments in Africa has however played an important role in the health outcomes of the citizens and affects the participation of labour in productive activities (Osundina, 2020).

Increasing labour force participation can help to achieve some of the SDGs, especially in the areas of decent jobs, poverty, inequality and even improved health condition. It has been argued that the increase in labour force participation would generate income that would enable people to have better access to healthcare. In fact, IreguiBohórquez et al. (2016) observed that people who participated in the labour force usually report better or sound health. A cursory look at labour force participation data, particularly in sub-Saharan Africa, shows that labour force participation has remained high but steadily decline over time until recent time. Besides this, there is uneven participation in the labour force across regions and gender. The average labour force participation between 1990 and 2019 stood at $69.9 \%$ which is greater than the world average within the same period $68.5 \%$. However, there is persist gender dichotomy in labour force participation in the region. While the male labour force participation stood at $76.3 \%$ that of their female counterparts stood at $63.6 \%$. A similar trend is observed for the youth labour force participation rate. The total youth labour force participation rate stood at $50.8 \%$. The gender gap in youth labour force participation stood at $5.5 \%$ as the male and female youth labour force participation rate stood at $53.6 \%$ and 
$48.1 \%$ respectively. However, the high rate of labour force participation in SSA, especially among the age bracket of 15-64 year, has been attributed to many factors. One of these factors according to ILO is the presence of the working-age population who are striving to survive the limited opportunities offered by their economies (ILO, 2018).

Many African countries are characterised by weak institutions which manifested in the form high rate of corruption, lack of accountability and transparency, political and social violence, neglect of or disregard for the rule of law and absence of government effectiveness. Of particular paramount in most African countries is the daily occurrence of corruption, especially among the government officials. The latest report by the Transparency International ranked most African countries high in the corruption perception index. Even the so called the biggest economy in Africa, Nigeria, ranked 146 out of 180 countries ranked in 2020. In fact, of most of the resource-endowed countries are characterised by high rate of corruption.

In light of the above, we examine the nexus between health expenditure and labour force participation taking into consideration the types of health expenditure (government health expenditure (hereafter GHE) and OOPHE and total and gender labour force participation for adults with age bracket (15-64). We also investigate the mediating role of institutional quality in health expenditure and labour force participation nexus. Investigating the mediating role of institutional quality becomes indispensable or crucial because the quality of institutions determines a lot of economic outcomes, including labour force participation (Acemoglu, et al. 2005; Acemoglu and Robinson, 2008; Acemoglu, 2010; Agovino, et al. 2019). There are ample of studies that have examined health expenditure and labour force participation (Faraget al.2013; Novignon, et al. 2015; Boachie and Ramu, 2016; Rauf, et al. 2018). Also, some studies have examined the relationship between institutional quality and health expenditure on one hand and institutional quality and labour force participation on the other hand ( $\mathrm{Su}$, et al. 2006; Cooray and Dzhumashev, 2018). However, to the best of our knowledge, we do not come across any study that has examined the role of institutional quality in the nexus between health expenditure and labour force participation, especially in Africa. This is the gap this study would fill.

We implement our study following four step estimation procedures. First, we estimate the relationship between health expenditure and labour force participation. The essence of this is to isolate the effect of health expenditure on labour force participation. This is important because if we include the other variables ab initio the impact of health expenditure on labour force participation may be crowded out. Second, we introduce institutional quality variable to ascertain the impact of institutional quality on labour force participation. Third, we add interactive term constructed from multiplication of health expenditure and institutional quality to determine the mediating role of institutional quality in health expenditure and labour force participation nexus. Fourth, we control for other variables that could serve as determinants labour force participation. These variables were selected based on a priori expectations and they include GDP per capita growth rate, life expectancy at birth, secondary school enrolment, infant mortality rate total fertility rate and trade openness. We deploy two estimation techniques which include panel fixed effects with Driscoll and Kraay (1998) standard errors and two-step system Generalised Method of Moments. Driscoll and Kraay's standard error in conjunction with panel fixed effects is used to address the issues heterogeneity and 
autocorrelation problems while the two-step system GMM is used to address endogeneity problem in the nexus between health expenditure and labour force participation.

A cursory look at our findings reveals that government health expenditure leads to an increment in labour force participation while out-of-pocket leads to a decline in labour force participation. Institutional quality appears to be detrimental to labour force participation. The interaction of the institutional quality with government health expenditure reduces the magnitude of the positive effect government expenditure on labour force participation.

Given the introduction, we proceed with the rest of the study as follows: section 2 reviews the existing studies. Section 3 focuses on data sources and some stylised facts on labour forces participation, health expenditure and quality of institutions. Section 4 presents the methodology. The results are presented in section 5 while section 6 concludes with policy implications.

\subsection{Literature review}

In the literature, health expenditure serves as one of the health inputs to produce good health as an output, which has been theorized through human capital theory. The role of human capital development has been theorized at the macro and micro level to show its importance on individual, households and the economy as a whole. At the macro level, the major discussion is centred around the channels through which health affect economic growth, while at the micro-level, the central highlight has been on how health inputs affect an individual's or household's health (health outcomes) in participating in both market and non-market activities. A modified neoclassical growth theory by Romer (1990) which emphasizes the role of human capital in creating new ideas for improved growth stated that a higher level of human capital will boost new technological development and spurs growth in the long run. However, it should be noted that education or health is usually used to proxy for human capital as a healthier individual has the opportunity to attend school and be ready to supply labour inputs that will yield improvement in growth. Hence, Romer (1990) and Barro (1991) emphasized that health is the most important factor in determining labour force participation. According to Becker (1962; 1964; 2009), human capital does not only include education, training and skills but also include health and other values embodied in individuals; which allow them to be more productive in an economy. The human capital theory developed by Grossman (1972) assumed that an individual has an initial level of health that depreciate/deteriorate as a result of time (Age) and can be improved through investment, especially with health inputs such as medical care which incorporates health expenditure, education, exercise et cetera to produce healthy time. Healthy time allows individuals to participate in non-labour and labour activities over their lifetime. Based on this theory, a healthy individual may decide to either used his/ her healthy time to participate in the labour market (supply labour units) and reinvest to gain healthy life or use it as leisure time (nonlabour activities) to derive utility as desired.

Methodology varies to the related study of this nature due to data proxies, data availability, cross country and single country analysis. There is no unique single methodology used by previous researchers related to this study because much of the studies dwell more on both health expenditure and economic growth or labour force participation and economic growth or labour force participation and health (see Piabuo and Tieguhong, 2017). Al-Jebory (2014), 
Ayanwu and Erhijakpor (2007), Farag et al. (2013), Piabuo and Tieguhong (2017), and Thu Ha (2018) used fixed, dynamics/ and random effect Panel ordinary least squares for cross country analysis to account for measurement error and autocorrelation. In the same vein, the use of the Generalized Method of Moments (GMM) by Isiaka (2020), Novignon et al.(2015) and Umoru and Yaqub (2015) was to address the autocorrelation due to the presence of the lagged dependent variable among explanatory variables, individual effect characterizing the heterogeneity among individuals and ordinary least squares (OLS) estimator biased. Other methods used in related studies for single-country analysis and baseline analysis are OLS, Nonlinear least squares, Autoregressive Distributive Lag (ARDL) and standard multinomial logit. In addition, two-stage least squares (R2SLS), three-stage -least -square (3SLS) and Newey-west test have been employed in a study by Ayanwu and Erhijakpor (2007), Boachie and Ramu (2015) and Anochiwaet al. (2019) to control for endogeneity, reverse causality and robustness of the estimator.

On the empirical front, there is paucity of research on health expenditure and labour force participation. However, studies have drawn possible results on the relationship between them using other channels like the link between health expenditure and growth, labour force participation and economic growth, and health expenditure and health outcomes. Al-Jebory (2014) examined the effects of health expenditures on population age distribution and labour participation rates among 84 countries from low- and high-income countries. He established that in high-income countries, health expenditure has a high influence on the labour force participation rates, while in low-income countries; health expenditure has low influences on the labour force participation rates. Similarly, Powell and Seabury (2013) confirmed that medical care spending can impact health and that health affects labour outcomes. Also, a study by Mushtaqet al. (2013) found evidence that health expenditure has a positive and significant impact on the labour force participation rate in the short run, but this result disappears in the long run. In addition, a recent study by Rauf et al. (2018) affirmed that labour force participation is increased by an increase in health expenditure, secondary school enrolment and Investment both in the short and long run. The results of other channels through which labour force participation/ health expenditure is affected by health/ economic growth or vice versa include the study from Australia by Laplagne (2007) and averred that better health and education can result in substantially greater labour force participation for those affected. Similarly, Novignon et al. (2015) showed that health status relates positively with labour force participation and relationship was significant for total and female labour force participation. Also, Isiaka (2020) confirmed that government spending increases the labour force participation rate in the West African Monetary Zone. On the health expenditure side, Ayanwu and Erhijakpor (2007) found that total health expenditures are certainly an important contributor to health outcomes. Farag et al. (2013) also confirmed that government health spending has a significant effect on improving health outcomes and the size of the coefficient depends on the level of good governance achieved by the country. In addition, Umoru and Yaqub (2015) suggested from their result that health capital investment enhances the productivity of the labour force. Similarly, Boachie and Ramu (2015) found evidence that falling health outcomes in Ghana has been influenced by public health spending among other factors. A most recent study by Anochiwa et al. (2019) also established that health expenditure is significant in determining health outcome but has no significant relationship with economic growth. Contrary to this submission, Thu Ha (2018) investigation suggested that countries with higher health expenditure and labour force participation rate are expected to have higher GDP. 
At the frontier of knowledge based on the role of institutions on health expenditure/ labour market participation, researchers have found the mediating role of quality of institution to be positive and highly significant Novignon (2015) has shown that high corruption and poor public sector institutions reduced health expenditure efficiency. Also, Makuta and O'Hare (2015) found that public spending impact is mediated by the quality of governance, which has a higher impact on health outcomes in countries with a higher quality of governance and lower impact in countries with lower quality of governance. It is also the case for Bousmah et al. (2016) and Dhrifi (2020) that institutional quality plays an important and significant role in health expenditure. The result from Massimiliano $e t$ al. (2019) has been able to identify that institutional quality has a positive effect on local labour market participation for both men and women in Italy but it does not affect the participation gap. Abstracting from empirical evidence that most of the studies merry-go-round the relationship between health expenditure and labour force participation with the exclusion of quality of institutions, this study contributes to knowledge by directly showing the empirical relationship between health expenditure and labour force participation as well as emphasizing on the imperative role of institutional quality.

\subsection{Data Sources and Stylised Facts}

\subsection{Data Sources and Description}

This study aims to investigate the role of institutional quality in the relationship between health expenditure and labour force participation. To achieve this aim, we utilise the data of 39 African countries covering the period from 2000 to 2018 . ${ }^{1} \mathrm{We}$ chose these countries due to the availability of relevant data. For the dependent variable, we use labour force participation for adults with age bracket (15-64) across gender, females and males. For independent variables, we use government domestic expenditure as a percentage of current health expenditure for the main analysis. For robustness analysis, we use out-of-pocket expenditure as a percentage of current health expenditure. We control for other variables based on the model of labour force participation and health expenditure model. These variables include GDP per capita growth rate, life expectancy at birth, female life expectancy at birth, male life expectancy at birth, secondary school enrolment, female secondary school enrolment, male secondary school enrolment, infant mortality rate, female infant mortality rate, male infant mortality rate, total fertility rate, and trade openness. All these variables including labour force participation and health expenditures data are obtained from the World Development Indicators (WDI). Based on the aim of this study, we construct an institutional index from six governance indicators which include control of corruption, government effectiveness, political stability, regulatory, rule of law and voice, and accountability. The Principal Component Analysis is used to compute the institutional quality index. Following Aluko and Ibrahim, (2020), Alagidede et al. (2020), Ibrahim and Vo (2020) and Raifu et al. (2021), the computed institutional quality index is winzorised to remove possible outliers in the institutional quality index. Thereafter, the winzorised institutional quality index is normalised so that its value ranges 0 and 1 with zero

\footnotetext{
${ }^{1}$ Algeria, Angola, Benin, Botswana, Burkina Faso, Burundi, Cabo Verde, Cameroon, Central African Republic, Chad, Comoros, Congo Democratic Republic, Congo Republic, Egypt, Equatorial Guinea, Eritrea, Ethiopia, Gambia, Ghana, Guinea, Kenya, Lesotho, Libya, Madagascar, Malawi, Mali, Mauritius, Morocco, Mozambique, Niger, Nigeria, Rwanda, Senegal, South Africa, Sudan, Togo and Tunisia.
} 
means poor institutional quality and 1 means good institutional quality. The governance variables are selected from the World Governance Indicators of the World Bank.

The summary statistics of the variables are presented in Table $1^{2}$. As shown in the Table, the average values of total labour force participation, male labour force participation, and female labour force participation are $66.1 \%, 75.1 \%$, and $57.2 \%$, respectively. This suggests that the labour force participation have been relatively high and increasing over time in Africa with its mean value been above average over the period considered. Government health expenditure (GHE) ranged from $4.1 \%$ to $77.5 \%$ of the current expenditure, with an average of $33.5 \%$ implying a relatively low $\%$ contribution to government health expenditure. The out-of-pocket (OOPHE) health expenditure is averaged at $42.5 \%$ with its lowest ebb of $2.99 \%$ and highest value at $84.2 \%$.

The institutional quality index ranged from 0 to 1 with an average value of 0.49 . This implies that the level of institutional quality in Africa is still below average. Although, there is a disparity of the institutional quality across the sampled African countries with some countries experiencing a relatively low standard of institutional policy while some still recorded high institutional efficiency of their policies. The average GDP per capita growth rate is $2.16 \%$, with a rangeof $62.4 \%$ to $121.8 \%$. The gap between the minimum and the maximum values of GDP growth rate as well as the standard deviation of 7.01\% reveals the wide disparity in GDP growth rate across Africa.

The average life expectancy at birth (LEAB) was 59.5\%. Female LEAB averaged $61.3 \%$ and male LEAB averaged $57.8 \%$. In addition, Secondary School Enrolment (SSE) averaged $48.7 \%$, with female SSE averaging $46.4 \%$ and male SSE averaging $50.9 \%$. The infant mortality rate (IMR) ranged from $10.3 \%$ to $121.2 \%$, with an average of $56.3 \%$. Also, male infant mortality (MIMR) ranged from $11.3 \%$ to $130.8 \%$ with an average value of $61.3 \%$, while female infant mortality (FIMR) ranged from $9.1 \%$ to $111.1 \%$ with a mean value of $51 \%$. With the measures of dispersion of LEAB, SSE, and IMR, it could be observed that there have been improvements in these indicators over time across Africa.

The total fertility rate ranged from $1.36 \%$ to $7.68 \%$ with an average value of $4.66 \%$. Trade openness has the minimum and maximum values of $17.93 \%$ and $193.48 \%$ respectively while being averaged at $70.93 \%$.

Table 1: Descriptive Statistics

\begin{tabular}{|c|c|c|c|c|c|c|c|c|c|}
\hline Variables & Obs & Mean & Std.Dev. & Min & $\operatorname{Max}$ & p1 & p99 & Skew. & Kurt. \\
\hline Labour Force Participation (LFP) & 741 & 66.090 & 12.353 & 42.390 & 90.340 & 43.270 & 88.510 & -0.097 & 1.879 \\
\hline Female LFP (FLFP) & 741 & 57.213 & 18.914 & 12.710 & 88.840 & 14.470 & 88.150 & -0.481 & 2.250 \\
\hline Male LFP (MLFP) & 741 & 75.072 & 8.881 & 50.740 & 92.160 & 52.600 & 91.860 & -0.265 & 2.588 \\
\hline Government Health Expenditure (GHE) & 741 & 33.487 & 17.285 & 4.062 & 77.476 & 5.250 & 73.001 & 0.606 & 2.558 \\
\hline Out-of-Pocket HE (OOPHE) & 741 & 42.542 & 20.471 & 2.993 & 84.162 & 4.574 & 80.661 & -0.085 & 2.035 \\
\hline Institutional Quality & 741 & 0.486 & 0.222 & 0.000 & 1.000 & 0.000 & 1.000 & 0.030 & 3.001 \\
\hline GDP per Capita Growth Rate & 741 & 2.160 & 7.077 & -62.378 & 121.780 & -12.443 & 13.743 & 5.947 & 127.472 \\
\hline Life Expectancy at Birth (LEAB) & 741 & 59.514 & 8.142 & 42.518 & 76.693 & 43.308 & 76.115 & 0.242 & 2.393 \\
\hline Female LEAB & 741 & 61.289 & 8.394 & 44.595 & 78.536 & 45.407 & 77.790 & 0.319 & 2.328 \\
\hline Male LEAB & 741 & 57.770 & 7.947 & 40.418 & 75.494 & 41.012 & 74.694 & 0.174 & 2.508 \\
\hline Secondary School Enrolment (SSE) & 741 & 48.729 & 28.082 & 6.197 & 153.412 & 8.624 & 138.852 & 0.899 & 3.624 \\
\hline
\end{tabular}

${ }^{2}$ Tables or figures not found in the main text are in the appendix. 


$\begin{array}{lrrrrrrrrr}\text { Female SSE } & 741 & 46.435 & 30.888 & 4.703 & 158.485 & 5.855 & 142.736 & 0.972 & 3.560 \\ \text { Male SSE } & 741 & 50.941 & 26.224 & 7.514 & 149.931 & 8.898 & 135.337 & 0.785 & 3.504 \\ \text { Infant Mortality Rate (IMR) } & 741 & 56.277 & 25.133 & 10.200 & 121.200 & 12.500 & 109.800 & 0.111 & 2.216 \\ \text { Female IMR } & 741 & 50.992 & 23.193 & 9.100 & 111.100 & 11.100 & 100.900 & 0.169 & 2.248 \\ \text { Male IMR } & 741 & 61.297 & 27.004 & 11.300 & 130.800 & 13.900 & 117.300 & 0.064 & 2.197 \\ \text { Total Fertility Rate } & 741 & 4.655 & 1.430 & 1.360 & 7.679 & 1.550 & 7.569 & -0.296 & 2.306 \\ \text { Trade Openness } & 741 & 70.934 & 32.559 & 17.927 & 193.483 & 21.853 & 172.092 & 0.999 & 3.789\end{array}$

Note: Compiled by the authors

\subsection{Stylised Facts of Health Expenditures and Labour Force Participation}

\subsubsection{Health expenditures in Africa}

Figure 1 shows the average GHE and OPP in selected African countries over the period of 2000 and 20008. A closer look at Figure 1 reveals that less than 12 countries among the selected countries have their shares of GHE higher than OOPHE health expenditure. For instance, on average, Algeria recorded the highest share of GHE out of the total health expenditure, followed by Libya, while the Republic of Congo recorded the lowest value of 9.04\%. One common characteristic among the countries with more than $65 \%$ of GHE is that they are among the top countries exporting refined natural resources in Africa. The periods between 2000 and 2018 which is 17 years after the 2001 Abuja declaration in the African region indicate that many of the countries in this region spent less than $15 \%$ of the total health expenditure. For OOPHE expenditure, which requires households to pay directly to a healthcare provider, Comoros recorded the highest percentage of $77.95 \%$, followed by Equatorial Guinea, while Botswana recorded the least value of $6.17 \%$. There are opposite fluctuations between the percentage shares of the two-health expenditure from the total health expenditure used for the graph. A country where the share of GHE is more than $50 \%$ of the total health expenditure is most likely to lessen the burden on households on the use of OOPHE payments. 
Figure 1: Government and Out-of-Pocket Health Expenditure in Africa

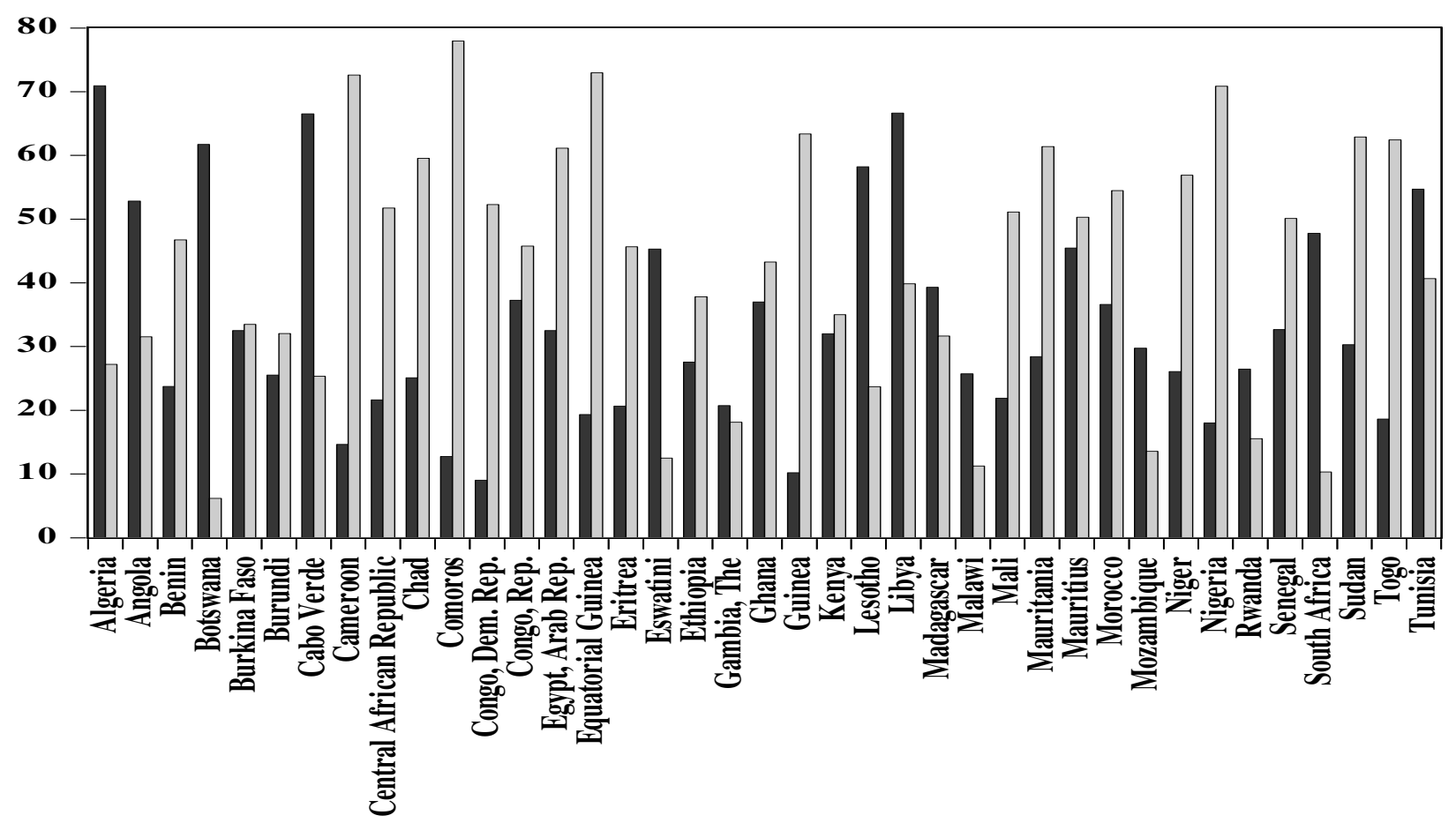

\section{Government Health Expenditure ( $\%$ of Current Health Expeniditure) Out-of-Pocket Health Expenditure ( $\%$ of Current Health Expeniditure)}

\subsubsection{Labour Force Participation}

Figure 2 shows the labour force participation in Africa between the ages of 15 and 65 years. As shown in the Figure, the highest average total labour participation between 2000 and 2018 was recorded in Madagascar (88.52\%). This country also exhibits the feminism of gender equality in Africa, in which the average gap between male and female labour participation rates was just a marginal percentage of $2.01 \%$. Rwanda also recorded an infinitesimal margin between average female and male labour participation rates. In most African countries, the labour market is more biased towards males. The gap is more obvious in countries where their religion and culture allow males to financially fend for the households. For instance, in Algeria, the average labour participation rate for males is 75.05\%, while females account for just 15.59\%. Similarly, Egypt also recorded an average female labour participation rate of $23.08 \%$, while males account for over $70 \%$. 
Figure 2: Labour Force Participation in Africa (15-64)

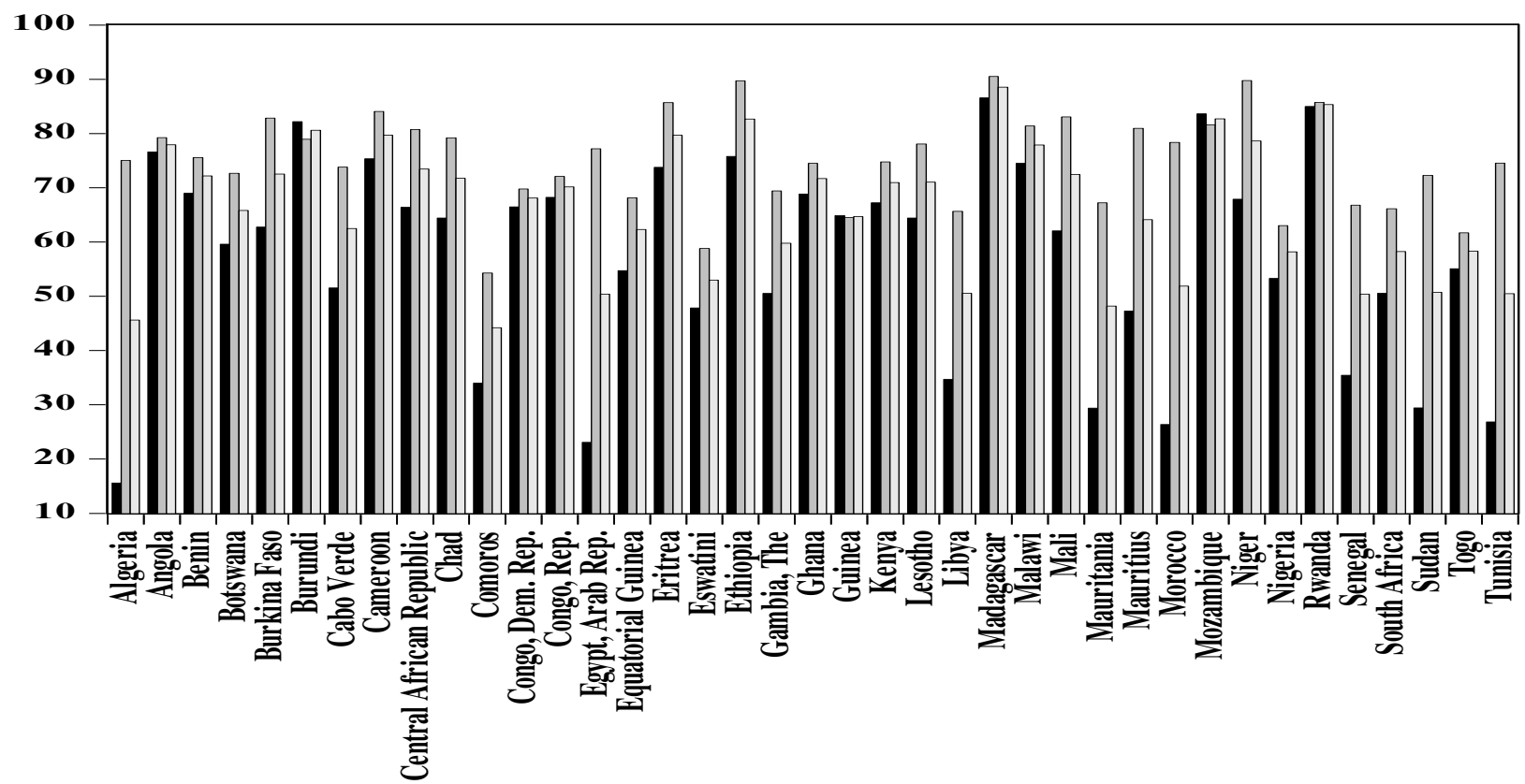

Female Labour Force Participation (1 5-64)

Male Labour Force Participation (15-64)

Total Labour Force Participation (15-64)

\subsubsection{Institutional Quality}

Figure 3 show, on average, the quality of institutions across the selected African countries. The quality of institutions is computed from six governance indicators which include control of corruption, government effectiveness, political stability, rule of law, regulatory quality and voice and accountability. We employed Principal Component Analysis for the computation of the institutional quality. The computed institutional quality index is winzorised and normalised so that its values range from 0 to 1 . This enables us to have a proper interpretation of the institutional quality. As in shown the Figure, it is evident that institutional quality varies across the selected African country. While some countries have good quality of institutions, moderate quality of institutional quality, the others are characterised by poor institutional quality. Among the selected African countries, Mauritius, Botswana, South Africa, Carbo Verde, Morocco, Ghana, Senegal and Tunisia have the best institutional quality. Countries such as Benin, Burkina Faso, Kenya, Madagascar and Mozambique have relatively better institutional quality above the threshold of 0.5 . However, most of the countries are characterised by poor quality of institutions. In fact, about 17 countries recorded below the threshold of institutional quality, that is, they are less than 0.5. These countries, among others, include Algeria, Burundi, Cameroon, Central African Republic, Chad, Comoros, Democratic Republic of Congo, Congo, Equatorial Guinea, Eritrea, Ethiopia, Guinea, Libya, Nigeria, Sudan and Togo. 
One of the prominent indicators of the existence of good or bad institutions in a given country is the level of corruption. In a highly corrupt country, the probability that other institutional quality indicators would be at a low ebb is very high. A highly corrupt country is likely to be characterised by disregard of rule of law, lack transparency and accountability among the officeholders and witnessing constant socio-political crises. According to Transparency International report of 2020, most of the countries in Africa are highly corrupt. Botswana is the least corrupt country in Africa, followed by Cabo Verde, Rwanda, Mauritius, Namibia, Sao Tome and Principe, Senegal, South Africa, Tunisia and Ghana respectively while countries such as South Sudan, Somalia, Sudan, Libya, Democratic Republic of Congo, Congo, Burundi, Eritrea, Comoro, Chad, Zimbabwe and Nigeria to mention but a few. Most of these highly corrupt countries fall among the countries we characterised as having poor institutional quality.

\section{Figure 3: Insititutional Quality Across African Countries}

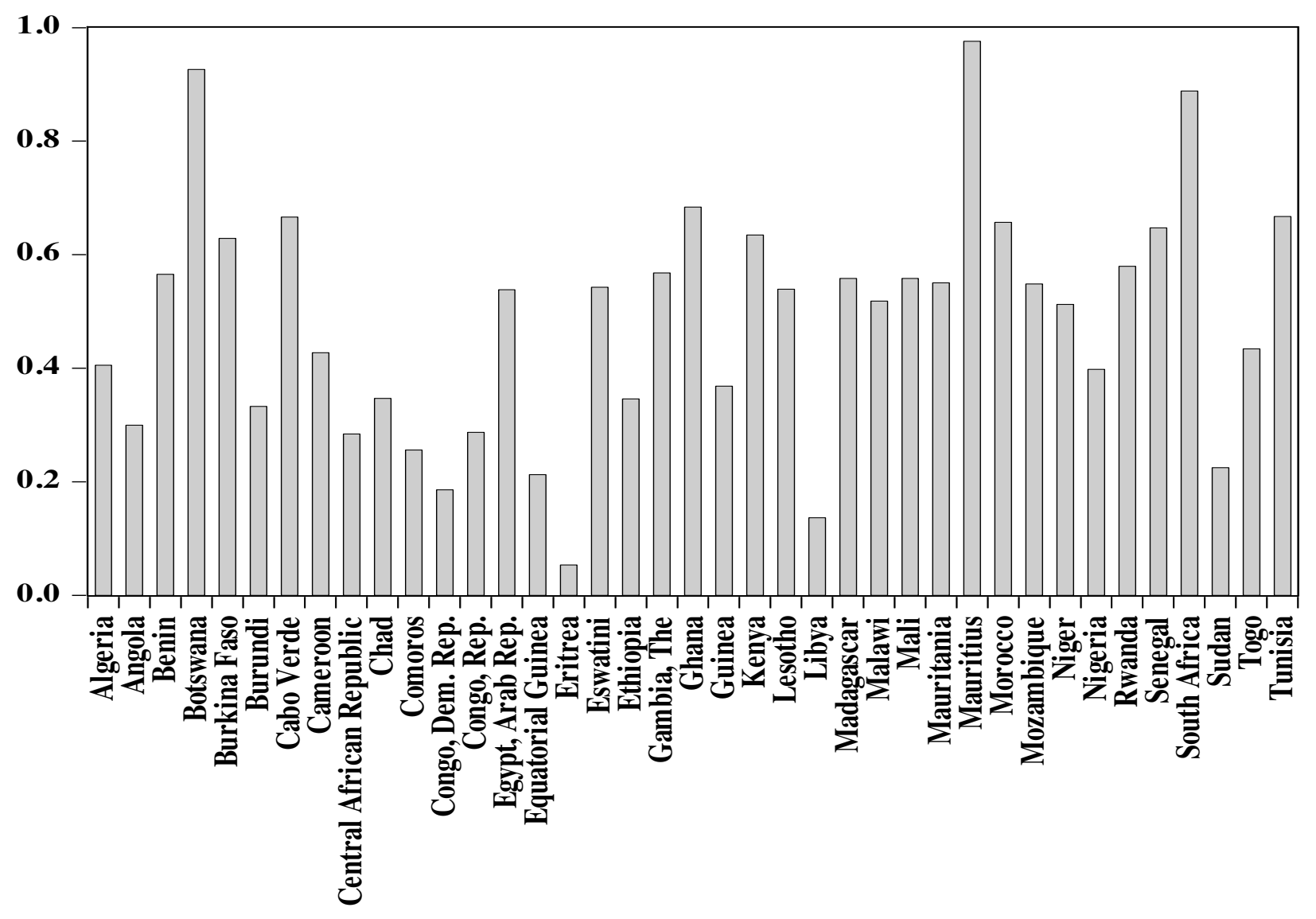

\subsection{The Relationship between Health Expenditure and Labour Force Participation}

\subsubsection{Domestic Government Health Expenditure and Labour Force Participation}

Figure 4 represents a scatter plot that shows the relationship between female labour participation rate (15-64) and domestic general GHE among the countries under consideration. The scatter plot indicates that there exists a linear negative relationship between the two variables. This, however, does not suggest that GHE does not encourage 
labour force participation but it does mean that governments in Africa like their counterparts in developing countries spends more on health to ensure that their citizens participate in the labour force (Devarajan, Swaroop and Zou, 1996). Moreover, a cursory look at the figure shows that few countries cluster along the fitted line. This is an indication that female labour force participation and domestic general GHE are linearly negative correlated in countries like Congo, Mali, South Africa, Libya, Burkina Faso, Chad, Equatorial Guinea, Botswana, and so on.

Figure 5 illustrates the relationship between male labour force participation and GHE. The fitted line is upward sloped suggesting a positive nexus between male labour force participation and GHE. This implies that an increase

in GHE would results in more male labour participation. The total labour participation rate with domestic GHE in figure 6 has a similar pattern with figure 4 . The fitted line is linear negative as represented on the scatter plot diagram. Close to half of the countries under consideration cluster along the fitted line. Examples of such countries are Congo, Mauritius, Guinea, South Africa, Cabo Verde, Nigeria, Kenya, Chad et cetera.

\subsubsection{Out-of-Pocket Health Expenditure and Labour Force Participation}

Figures 7 to 9 plot the relationship between labour force participation (female, male and total) and OOPHE health expenditure. The three fitted values' lines demonstrate similar attribute. The lines move from up to down to indicate linear negative relationships. In figure 7, a reduction in OOPHE health expenditure leads to reduction in female labour participation rate. Similarly, there is a linear negative correlation between male labour participation rate and OOPHE health expenditure. The total labour participation rate also exhibits similar behaviour with OOPHE health expenditure as that of female and male labour participation rates. 

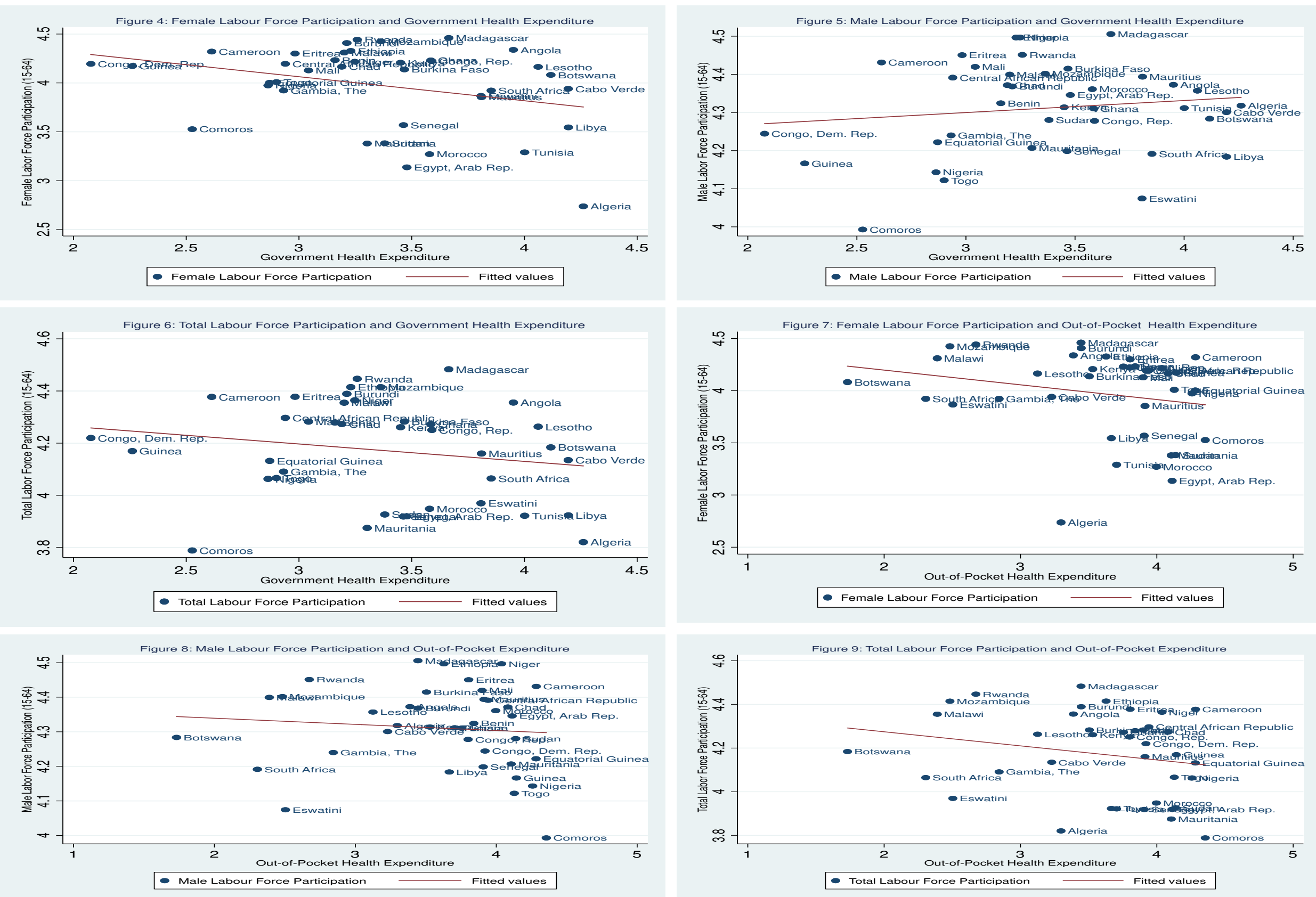


\subsection{Methodology}

Modelling health expenditure or status and labour force participation nexus has been controversial due to the issue of endogenous bias (Cai and Kalb, 2006). One strand of argument posits that health expenditure being a health input affects labour force participation. The amount of expenditure, particularly by the government, determines the provision and availability of healthcare facilities which in turn also determines the access to healthcare and improvement in the health status of the citizens. When the citizen's health status improves due to access to the available healthcare facilities, they tend to be more participating in the labour force and improve their productivity. Thus, health expenditure assumes to have a positive effect on labour force participation judging by human capital theory (Laplagne, Glover and Shomos, 2007). Conversely, people with poor health tend not to participate in the labour force. Another argument posits that labour force participation affects healthcare status or expenditure (Waghorn and Lloyd, 2005). It has been argued that participating in some works may have a detrimental effect on the health of the workforce. Some works lead to stress and create mental health for the labours. However, ill-health may motivate an individual to participate in the labour force in order to raise income to take care of his health condition (Stern, 1989; Laplagne et al., 2007).

In this study, we are particularly interested in addressing two issues in modelling the mediating role of institutional quality in health expenditure-labour force participation nexus in Africa. The first is to address the spatial dependence or cross-sectional dependence among the countries that have some sorts of similar characteristics or coalition among the countries. Hence, using conventional ordinary panel OLS as a method of estimation would lead to inconsistent estimated standard error (Driscoll and Kraay, 1998). Given this, Driscoll and Kraay (1998) developed a nonparametric covariance estimation method that yields a robust standard error. The method is also useful when the model is prone to heteroscedasticity and autocorrelation problems (see Hoechle, 2007). Thus, we adopt this method under the fixed effects estimation method. The second issue addressed is the issue of endogeneity between health expenditure and labour force participation as argued above. To address endogeneity between the two variables, early studies used the two-stage-least-squares estimation method using two-stage approaches (see Stern, 1989; Cai and Kalb, 2006; Cai, 2010). In this study, we follow Nonvignon et al. (2015) by employing the dynamic system Generalised Method of Moments (GMM) developed by Arellano and Bover (1995) and Blundell and Bond (1998). Following the argument above, we proceed to model specification.

Assume a simple regression in which labour force participation depends on health expenditure and other control variables, we specify linear fixed effect regression as follows:

$$
L P_{i t}=\alpha+\beta H E_{i t}+X^{\prime} \gamma+U_{i}+V_{i t}
$$

Where $L P$ is labour force participation rate, $H E$ designates health expenditure and $X$ is a set of control variables used as explanatory variables aside from health expenditure, $\alpha$ is a constant, $U$ is a country-specific effect and $V$ is the error term assumed to be normally distributed with zero mean and constant variance. We consider labour force participation for adults (15-64) and youths (14-25) across gender, males and female. We also use two forms of 
health expenditure and they include domestic GHE as a percentage of current health expenditure and OOPHE health expenditure as a percentage of current health expenditure. Domestic GHE is used for the main analysis while OOPHE health expenditure is used for robustness analysis. Other sets of explanatory variables include GDP per capita growth rate, life expectancy at birth (total, female and male), gross secondary school enrolment (total, female and female), infant mortality rate (total, female and male), total fertility rate, and trade openness. These variables are included whether we are considering total labour force participation, female labour force participation or male labour force participation for adults and youths.

Considering the main aim of this study, we modify equation 1 to allow for the role of institutional quality as follows:

$$
L P_{i t}=\alpha+\beta H E_{i t}+\lambda I N S T_{i t}+\theta\left(I N S T^{*} H E\right)_{i t}+X^{\prime} \gamma+U_{i}+V_{i t}
$$

Other variables remain as previously defined. INST is the institutional quality and INST * HE is the interaction of institutional quality with health expenditure which shows the indirect channel through which health expenditure affects labour force participation. The equations 1 and 2 are estimated using panel fixed effects with Driscoll and Kraay (1998) standard errors.

However, to address the endogeneity problem, we use a dynamic two-stage system GMM. We begin the presentation of the two-step system GMM by incorporating the lag of dependent variable into equation 2 with slight modification as follow:

$$
L P_{i t}=\alpha+\phi L P_{i t-1}+\beta H E_{i t}+\lambda I N S T_{i t}+\theta\left(I N S T^{*} H E\right)_{i t}+X^{\prime} \gamma+V_{i t}
$$

Based on a priori expectation, $\phi$ could either be 0 or 1 . If $\phi<1$, it means that labour force participation declines over time and it does not persist into the future. However, if $\phi>1$, it means that the past and present labour force participation persists into the future. This suggests that countries with a high level of labour force participation continue to increase in labour force participation in the future. Depending on the quality of institutions possessed by a country or a group of countries, institutions could have a positive or negative effect on labour force participation. In a country characterised by poor institutional quality, especially a high rate of corrupt practices among the government officials, money meant to finance the provision of healthcare facilities may be misappropriated or end up in some coffer of some unscrupulous government officials. This could lead to a lack of insufficient healthcare provision and delivery with a negative effect on the health status of the citizens and their labour force participation. The reverse is the case for a country or a group of countries with high-quality institutions. $\theta$ is the coefficient of the interactive term of institutional quality and health expenditure (INST *HE). This coefficient shows that whether or not institutional quality influences positively or negatively the relationship between health expenditure and labour force participation. Thus, when $\theta$ is positive and statistically significant, then it implies that institutional quality and health expenditure are complementarities in influencing labour force participation. Here, $V_{i t}=\chi_{i}+\rho_{t}+v_{i t}$ 
where $\chi_{i}$ is an unobserved country-specific fixed effect, $\rho_{t}$ is the time effect and $v_{i t}$ is the error term. According to Roodman (2009a, b), estimating equation 3 by OLS would suffer two problems- identification and endogeneity problems. To overcome these problems, especially the problem of endogeneity, we use a two-step system GMM. The two-step system GMM entails two main approaches. It is possible to use the lagged differences of the dependent variable as instruments for level equations and the first differenced equation (Arellano and Bover, 1995). In practice, however, one must avoid the pitfall of instrument proliferations. To avoid this pitfall, Roodman (2009a, b) suggests that the researcher should collapse the instruments.

\subsection{Empirical Findings}

\subsection{Correlation Analysis Results}

Table 2 reports the results of the correlation analysis among the variables of interest. The correlation value $(r=-$ 0.158 ) between the total labour force participation and GHE shows a negative and significant relationship between the variables. Also, there is a negative level of correlation $(r=-0.199)$ between total labour force participation and OOPHE health expenditure. This is in tandem with what we found from the scatter diagrams. In addition, evidence of negative correlations is established between labour force participation and trade openness life expectancy and secondary school enrolment variables. However, mortality rate variables and total fertility are positively correlated with labour force participation. Among the repressors, the correlations are moderate with varying level of signs and significance. This indicates that the problem of multicollinearity not an issue among the repressors. 
Table 2: Pairwise Correlation Test Results

\begin{tabular}{|c|c|c|c|c|c|c|c|c|c|c|c|c|c|c|c|c|c|c|}
\hline Variables & Lfpat & Lfpaf & Ifpam & ldgghe & loope & linstn & gdppcapgr & lleabt & lleabf & lleabm & lgsse & Lgssef & lgssem & limr & limrf & limrm & ltfr & Ltopen \\
\hline lfpat & 1 & & & & & & & & & & & & & & & & & \\
\hline lfpaf & $0.913^{*}$ & 1 & & & & & & & & & & & & & & & & \\
\hline lfpam & $0.727 *$ & $0.399 *$ & 1 & & & & & & & & & & & & & & & \\
\hline ldgghe & $-0.158 *$ & $-0.277^{*}$ & $0.120^{*}$ & 1 & & & & & & & & & & & & & & \\
\hline loope & $-0.199 *$ & $-0.205^{*}$ & $-0.086^{*}$ & $-0.428^{*}$ & 1 & & & & & & & & & & & & & \\
\hline linstn & 0.018 & -0.027 & $0.127 *$ & $0.310^{*}$ & $-0.344 *$ & 1 & & & & & & & & & & & & \\
\hline gdppcapgr & 0.001 & -0.011 & 0.027 & 0.024 & -0.009 & -0.035 & 1 & & & & & & & & & & & \\
\hline lleabt & $-0.423 *$ & $-0.562 *$ & -0.013 & $0.318^{*}$ & 0.046 & $0.159 *$ & 0.01 & 1 & & & & & & & & & & \\
\hline lleabf & $-0.424 *$ & $-0.560 *$ & -0.015 & $0.362 *$ & -0.007 & $0.174^{*}$ & 0.013 & $0.995^{*}$ & 1 & & & & & & & & & \\
\hline lleabm & $-0.423 *$ & $-0.564 *$ & -0.013 & $0.274 *$ & $0.100^{*}$ & $0.141^{*}$ & 0.007 & $0.995^{*}$ & $0.981^{*}$ & 1 & & & & & & & & \\
\hline lgsse & $-0.527 *$ & $-0.483^{*}$ & $-0.400^{*}$ & $0.367^{*}$ & $-0.211 *$ & $0.190^{*}$ & -0.001 & $0.626^{*}$ & $0.654^{*}$ & $0.597 *$ & 1 & & & & & & & \\
\hline lgssef & $-0.505^{*}$ & $-0.477^{*}$ & $-0.355^{*}$ & $0.437 *$ & $-0.266^{*}$ & $0.222^{*}$ & 0.005 & $0.630^{*}$ & $0.662 *$ & $0.597 *$ & $0.981^{*}$ & 1 & & & & & & \\
\hline lgssem & $-0.536 *$ & $-0.480^{*}$ & $-0.427^{*}$ & $0.283^{*}$ & $-0.150 *$ & $0.159^{*}$ & 0.000 & $0.609 *$ & $0.631^{*}$ & $0.585^{*}$ & $0.984 *$ & $0.937 *$ & 1 & & & & & \\
\hline limr & $0.395^{*}$ & $0.492 *$ & 0.042 & $-0.545^{*}$ & $0.208^{*}$ & $-0.286^{*}$ & -0.018 & $-0.835^{*}$ & $-0.863^{*}$ & $-0.802^{*}$ & $-0.782 *$ & $-0.798^{*}$ & $-0.744 *$ & 1 & & & & \\
\hline limrf & $0.389^{*}$ & $0.483^{*}$ & 0.041 & $-0.540 *$ & $0.205^{*}$ & $-0.281 *$ & -0.018 & $-0.835 *$ & $-0.863^{*}$ & $-0.802 *$ & $-0.782 *$ & $-0.799 *$ & $-0.744 *$ & $0.999 *$ & 1 & & & \\
\hline limrm & $0.399 *$ & $0.498 *$ & 0.042 & $-0.548 *$ & $0.210^{*}$ & $-0.289 *$ & -0.018 & $-0.835 *$ & $-0.863 *$ & $-0.802 *$ & $-0.780 *$ & $-0.797 *$ & $-0.743 *$ & $1.000 *$ & $0.998 *$ & 1 & & \\
\hline ltfr & $0.456^{*}$ & $0.521 *$ & $0.147 *$ & $-0.580^{*}$ & $0.243^{*}$ & $-0.307^{*}$ & -0.042 & $-0.632 *$ & $-0.676^{*}$ & $-0.586 *$ & $-0.779 *$ & $-0.798^{*}$ & $-0.734 *$ & $0.855^{*}$ & $0.851 *$ & $0.857 *$ & 1 & \\
\hline Ltopen & $-0.119 *$ & -0.06 & $-0.168 *$ & $0.395 *$ & $-0.181 *$ & $0.101 *$ & $0.097 *$ & 0.057 & $0.089 *$ & 0.026 & $0.327 *$ & $0.332 *$ & $0.303^{*}$ & $-0.242 *$ & $-0.243 *$ & $-0.242 *$ & $-0.397 *$ & 1 \\
\hline
\end{tabular}

* shows significance at the 0.05 level

Note: Ifpat, lfpaf, lfpam, ldgghe, loope, linstn, gdppcapgr, lleabt, lleabf, lleabm, lgsse, lgssef, lgssem, limr, limrf, limrm, ltfr and ltopen are total labour force participation rate (LFP), female LFP, male LFP, government health expenditure (HE), out-of-pocket HE, GDP per capita growth rate, life expectancy at birth (LEAB ), female LEAB, male LEAB, secondary school enrolment (SSE), female SSE, male SSE, infant mortality rate (IMR), female IMR, male IMR, total fertility rate and trade openness respectively. 


\subsection{Main Results: The Effect of Government Health Expenditure and Its Interaction with Institutional Quality on Labour Force Participation}

The key findings of the study are presented and discussed in this section. The study estimated four different models to implement the impact of the institutional role and health expenditure on labour force participation (LFP) in Africa. The first model estimated the effect of health expenditure alone on LFP. The second model considered the effect of health expenditure and institutional quality which were estimated on LFP. The third model included interactive term (that is, institutional quality and health expenditure) as one of the independent variables. Hence, health expenditure, institutional quality and interactive term were the independent variables in this model. The fourth model included control variables (such as GDP per capita growth, life expectancy at birth, secondary school enrolment, infant mortality rate, total fertility rate, and trade openness) which can serve as determinants of LFP. Each of the four different model(s) was estimated on total, female, and male LFP respectively.

Tables 3 and 4 show the effect of domestic GHE and institutional quality on LFP in Africa using panel fixed effects with Driscoll and Kraay (1998) standard errors and dynamic GMM approach respectively. We begin the presentation of the results by presenting the results of Panel Fixed Effects with Driscoll and Kraay (1998) standard errors. As shown in Table 3, domestic GHE appears to have a positive effect on LFP (total, female and male) when we regress labour force participations on domestic GHE but the positive effect is not statistically significant. However, the introduction of institutional quality in the second model allows for a positive and significant relationship to be observed between domestic GHE and LFP. Specifically, a percentage increase in GHE raises total and female LFP by $0.005 \%$ and $0.006 \%$ respectively. This is similar to the findings of Al-Jebory (2014), Isiaka (2020) and Raufet al., (2018) revealing that health expenditure has a positive influence on LFP rate.

Though, institutional quality has a negative influence on LFP, suggesting that poor institutional quality in Africa discourages LFP. This means that an upwards trend in poor institutional quality leads to a decline in total and female LFP by $0006 \%$ and $0.012 \%$ respectively. When the institutional quality is interacted with GHE, the resulting finding reveals a positive and significant effect on total, female and male LFP. This is in line with the findings of Dhrifi (2020) and Massimiliano et al., (2019). However, a closer look at the estimated coefficients across the models, we could see that the coefficients of interaction are lower than the estimated coefficients of GHE alone. This means that poor institutional quality in Africa tends to reduce the positive effect of GHE on labour force participation.

The impact of the control variables captured in the final model revealed that life expectancy at birth (LEAB) spurs total, female, and male LFP by $0.223 \%, 0.190 \%$ and $0.192 \%$ respectively. However, secondary school enrolment (SSE) tends to reduce total, female, and male LFP. The effect of infant mortality rate (IMR) is not statistically significant on total and female LFP rate. It is, however, positive and statistically significant on male labour LFP. Total fertility rate (TFR) is also found to positively influence female LFP, suggesting that the increase in the rate of fertility could gear up women to participate in the labour force as they have many children to feed. Trade openness is detrimental to female labour force participation

We would now examine the consistency of the above results when we control for endogeneity in the relationship between GHE and LFP as well as other variables when we use the two-stage system GMM. As observed in Table 4, 
we obtain more consistent results from the GMM which is conformed to the economic expectations. However, the presentation of the results begins with the results of the diagnostic tests. It can be shown that the numbers of groups are found to be greater than the number of instruments used, revealing the validity of the instruments. Furthermore, the post-estimation findings revealed that endogeneity problems had been properly addressed. The second-order autocorrelation values reject the existence of second-order autocorrelation and thus, we accept the null hypothesis of no autocorrelation. Consequently, our models do not suffer from second-order serial autocorrelation (AR (2)). Also, the Hansen / Sagan test of over-identification of instruments results indicates that the instruments included are valid. The fourth models were found to be more reliable. Another important result reported in Table 4 is the result of the lag of dependent variable (LFP). As shown in the Table, a period lag of LFP itself is positive and significant on the current LFP. This implies that previous LFP improves the contemporary LFP in all the models.

GHE has relatively low positive effects on total and female LFP. In specific term, an increase in GHE would spur total and female LFP by about $0.022 \%$ and $0.030 \%$ respectively. The empirical finding of Al-Jebory (2014) supports the positive effect of health expenditure on LFP. When the institutional quality is introduced the positive effect of GHE is now statistically significant on male LFP. In all the models, it is evident that institutional quality negatively affects all categories of LFP. The interaction of institutional quality and health expenditure though has a positive effect on all LFP, the positive effect occurs at a decreasing rate, suggesting the weight of poor institutional quality in the continent of Africa actually pull down the positive effect of GHE on LFP. 
Table 3: Effects of Government Health Expenditure and Its Interaction with Institutional Quality on Labour Force Participation in Af rica

\begin{tabular}{|c|c|c|c|c|c|c|c|c|c|c|c|c|}
\hline & \multicolumn{4}{|c|}{ Model 1} & \multicolumn{4}{|c|}{ Model 2} & \multicolumn{4}{|c|}{ Model 3} \\
\hline & \multicolumn{4}{|c|}{ Total Labour Force Participation } & \multicolumn{4}{|c|}{ Female Labour Force Participation } & \multicolumn{4}{|c|}{ Male Labour Force Participation } \\
\hline GHE & $\begin{array}{c}0.003 \\
(0.003)\end{array}$ & $\begin{array}{l}0.005^{*} \\
(0.003)\end{array}$ & $\begin{array}{c}0.015^{* * *} \\
(0.003)\end{array}$ & $\begin{array}{c}0.010 * * \\
(0.004)\end{array}$ & $\begin{array}{c}0.001 \\
(0.002)\end{array}$ & $\begin{array}{c}0.006 * * * \\
(0.002)\end{array}$ & $\begin{array}{c}0.015 * * * \\
(0.003)\end{array}$ & $\begin{array}{c}0.010 * * * \\
(0.003)\end{array}$ & $\begin{array}{c}0.000 \\
(0.004)\end{array}$ & $\begin{array}{c}0.001 \\
(0.004)\end{array}$ & $\begin{array}{l}0.009 * \\
(0.004)\end{array}$ & $\begin{array}{c}0.005 \\
(0.004)\end{array}$ \\
\hline IST & & $\begin{array}{c}-0.006 * * \\
(0.003)\end{array}$ & $\begin{array}{c}-0.031 * * * \\
(0.004)\end{array}$ & $\begin{array}{c}-0.017 * * \\
(0.007)\end{array}$ & & $\begin{array}{c}-0.012 * * \\
(0.005)\end{array}$ & $\begin{array}{c}-0.034 * * * \\
(0.005)\end{array}$ & $\begin{array}{c}-0.020 * * * \\
(0.006)\end{array}$ & & $\begin{array}{l}-0.004 \\
(0.003)\end{array}$ & $\begin{array}{c}-0.023^{* * *} * \\
(0.004)\end{array}$ & $\begin{array}{l}-0.012 * \\
(0.007)\end{array}$ \\
\hline GHE*IST & & & $\begin{array}{c}0.008 * * * \\
(0.001)\end{array}$ & $\begin{array}{l}0.005^{*} \\
(0.003)\end{array}$ & & & $\begin{array}{c}0.007 * * * \\
(0.003)\end{array}$ & $\begin{array}{c}0.003 \\
(0.003)\end{array}$ & & & $\begin{array}{c}0.006 * * * \\
(0.001)\end{array}$ & $\begin{array}{c}0.005 \\
(0.003)\end{array}$ \\
\hline GDPPCGR & & & & $\begin{array}{l}-0.000 \\
(0.000)\end{array}$ & & & & $\begin{array}{l}-0.000 \\
(0.000)\end{array}$ & & & & $\begin{array}{l}-0.000 \\
(0.000)\end{array}$ \\
\hline LEAB & & & & $\begin{array}{c}0.223 * * * \\
(0.034)\end{array}$ & & & & $\begin{array}{c}0.190 * * * \\
(0.065)\end{array}$ & & & & $\begin{array}{c}0.192 * * * \\
(0.024)\end{array}$ \\
\hline SSE & & & & $\begin{array}{c}-0.060 * * * \\
(0.008)\end{array}$ & & & & $\begin{array}{c}-0.044 * * * \\
(0.008)\end{array}$ & & & & $\begin{array}{c}-0.054 * * * \\
(0.009)\end{array}$ \\
\hline IMR & & & & $\begin{array}{c}0.018 \\
(0.013)\end{array}$ & & & & $\begin{array}{l}-0.037 \\
(0.037)\end{array}$ & & & & $\begin{array}{c}0.047 * * * \\
(0.008)\end{array}$ \\
\hline TFR & & & & & & & & $\begin{array}{c}0.051^{* *} \\
(0.019)\end{array}$ & & & & \\
\hline TOPEN & & & & $\begin{array}{c}-0.005 \\
(0.004)\end{array}$ & & & & $\begin{array}{c}-0.019^{*} \\
(0.010)\end{array}$ & & & & $\begin{array}{c}0.002 \\
(0.004)\end{array}$ \\
\hline _cons & $\begin{array}{c}4.164 * * * \\
(0.010)\end{array}$ & $\begin{array}{c}4.148 * * * \\
(0.012)\end{array}$ & $\begin{array}{c}4.117 * * * \\
(0.014)\end{array}$ & $\begin{array}{c}3.401 * * * \\
(0.162)\end{array}$ & $\begin{array}{c}3.970 * * * \\
(0.009)\end{array}$ & $\begin{array}{c}3.942 * * * \\
(0.009)\end{array}$ & $\begin{array}{c}3.914 * * * \\
(0.012)\end{array}$ & $\begin{array}{c}3.452 * * * \\
(0.395)\end{array}$ & $\begin{array}{c}4.310 * * * \\
(0.015)\end{array}$ & $\begin{array}{c}4.302 * * * \\
(0.017)\end{array}$ & $\begin{array}{c}4.279 * * * \\
(0.019)\end{array}$ & $\begin{array}{c}3.529 * * * \\
(0.088)\end{array}$ \\
\hline Obs. & 741 & 721 & 721 & 721 & 741 & 721 & 721 & 721 & 741 & 721 & 721 & 721 \\
\hline Within $\mathrm{R}^{2}$ & 0.0005 & 0.0078 & 0.0209 & 0.2319 & 0.0001 & 0.0098 & 0.0139 & 0.0781 & 0.0000 & 0.0026 & 0.0091 & 0.2527 \\
\hline F-statistics & $\begin{array}{c}0.800 \\
(0.3839)\end{array}$ & $\begin{array}{c}2.590 \\
(0.1023)\end{array}$ & $\begin{array}{c}24.500 \\
(0.0000)\end{array}$ & $\begin{array}{l}145.580 \\
(0.0000)\end{array}$ & $\begin{array}{c}0.370 \\
(0.5523)\end{array}$ & $\begin{array}{c}5.870 \\
(0.0109)\end{array}$ & $\begin{array}{c}18.750 \\
(0.0000)\end{array}$ & $\begin{array}{l}278.770 \\
(0.0000)\end{array}$ & $\begin{array}{c}0.010 \\
(0.9438)\end{array}$ & $\begin{array}{c}1.280 \\
(0.3013)\end{array}$ & $\begin{array}{c}11.810 \\
(0.0002)\end{array}$ & $\begin{array}{c}76.890 \\
(0.0000)\end{array}$ \\
\hline
\end{tabular}


Table 4: Effects of Government Health Expenditure and Its Interaction with Institutional Quality on Labour Force Participation in Africa

\begin{tabular}{|c|c|c|c|c|c|c|c|c|c|c|c|c|}
\hline 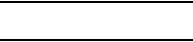 & \multicolumn{4}{|c|}{ Total Labour Force Participation } & \multicolumn{4}{|c|}{ Female Labour Force Participation } & \multicolumn{4}{|c|}{ Male Labour Force Participation } \\
\hline Lag LFP & $\begin{array}{c}1.019 * * * \\
(0.011)\end{array}$ & $\begin{array}{c}0.994 * * * \\
(0.002)\end{array}$ & $\begin{array}{c}1.000 * * * \\
(0.005)\end{array}$ & $\begin{array}{c}1.011 * * * \\
(0.009)\end{array}$ & $\begin{array}{c}1.002 * * * \\
(0.005)\end{array}$ & $\begin{array}{c}0.994 * * * \\
(0.001)\end{array}$ & $\begin{array}{c}0.997 * * * \\
(0.003)\end{array}$ & $\begin{array}{c}1.022 * * * \\
(0.009)\end{array}$ & $\begin{array}{c}0.997 * * * \\
(0.030)\end{array}$ & $\begin{array}{c}0.993 * * * \\
(0.003)\end{array}$ & $\begin{array}{c}0.993 * * * \\
(0.003)\end{array}$ & $\begin{array}{c}1.022 * * * \\
(0.015)\end{array}$ \\
\hline GHE & $\begin{array}{c}0.022 * * \\
(0.010)\end{array}$ & $\begin{array}{c}0.002 * * \\
(0.001)\end{array}$ & $\begin{array}{c}0.052 * * * \\
(0.009)\end{array}$ & $\begin{array}{c}0.008 * * * \\
(0.002)\end{array}$ & $\begin{array}{c}0.030 * * * \\
(0.008)\end{array}$ & $\begin{array}{c}0.005 * * * \\
(0.001)\end{array}$ & $\begin{array}{c}0.051 * * * \\
(0.013)\end{array}$ & $\begin{array}{c}0.007 \\
(0.011)\end{array}$ & $\begin{array}{c}0.005 \\
(0.018)\end{array}$ & $\begin{array}{c}0.002 * * \\
(0.001)\end{array}$ & $\begin{array}{c}0.008 * * \\
(0.003)\end{array}$ & $\begin{array}{c}0.005 * * \\
(0.003)\end{array}$ \\
\hline IST & & $\begin{array}{c}-0.003 * * * \\
(0.001)\end{array}$ & $\begin{array}{c}-0.170 * * * \\
(0.035)\end{array}$ & $\begin{array}{c}-0.006 * * * \\
(0.002)\end{array}$ & & $\begin{array}{c}-0.003 * * \\
(0.001)\end{array}$ & $\begin{array}{c}-0.156^{* * * *} \\
(0.051)\end{array}$ & $\begin{array}{l}-0.008 \\
(0.008)\end{array}$ & & $\begin{array}{c}-0.004 * * * \\
(0.001)\end{array}$ & $\begin{array}{c}-0.021 * * \\
(0.010)\end{array}$ & $\begin{array}{c}-0.011 * * * \\
(0.002)\end{array}$ \\
\hline GHE*IST & & & $\begin{array}{c}0.054 * * * \\
(0.011)\end{array}$ & $\begin{array}{c}0.002 * * * \\
(0.001)\end{array}$ & & & $\begin{array}{c}0.052 * * * \\
(0.016)\end{array}$ & $\begin{array}{c}0.004 \\
(0.003)\end{array}$ & & & $\begin{array}{l}0.005^{*} \\
(0.003)\end{array}$ & $\begin{array}{c}0.003^{* * * *} \\
(0.001)\end{array}$ \\
\hline GDPPCGR & & & & $\begin{array}{l}-0.000 \\
(0.000)\end{array}$ & & & & $\begin{array}{c}0.000 \\
(0.000)\end{array}$ & & & & $\begin{array}{c}-0.000 * * * \\
(0.000)\end{array}$ \\
\hline LEAB & & & & $\begin{array}{c}-0.185^{* * *} \\
(0.036)\end{array}$ & & & & $\begin{array}{c}-0.146^{*} \\
(0.074)\end{array}$ & & & & $\begin{array}{c}-0.208 * * * * \\
(0.037)\end{array}$ \\
\hline SSE & & & & $\begin{array}{c}0.012^{* *} \\
(0.005)\end{array}$ & & & & $\begin{array}{c}0.010 \\
(0.012)\end{array}$ & & & & $\begin{array}{c}0.019 * * * \\
(0.006)\end{array}$ \\
\hline IMR & & & & $\begin{array}{c}-0.043 * * * \\
(0.010)\end{array}$ & & & & $\begin{array}{c}0.028 \\
(0.020)\end{array}$ & & & & $\begin{array}{c}-0.044 * * * \\
(0.011)\end{array}$ \\
\hline TFR & & & & & & & & $\begin{array}{c}-0.142 * * * \\
(0.039)\end{array}$ & & & & \\
\hline TOPEN & & & & $\begin{array}{c}-0.004 * * \\
(0.002)\end{array}$ & & & & $\begin{array}{c}-0.023 * * \\
(0.010)\end{array}$ & & & & $\begin{array}{c}0.009 * * * \\
(0.002)\end{array}$ \\
\hline _cons & $-0.154 * * *$ & 0.015 & $-0.172 * * *$ & $0.826 * * *$ & $-0.109 * *$ & 0.005 & $-0.148 * * *$ & $0.660 * *$ & -0.007 & 0.019 & -0.004 & $0.791 * * *$ \\
\hline Ohs & $(0.055)$ & $(0.010)$ & $(0.042)$ & $(0.194)$ & $(0.041)$ & $(0.009)$ & $(0.047)$ & $(0.325)$ & $(0.122)$ & $(0.012)$ & $(0.019)$ & $(0.194)$ \\
\hline Obs. & 702 & 683 & 683 & 683 & 702 & 683 & 683 & 683 & 702 & 683 & 683 & 683 \\
\hline F-statistics & $\begin{array}{c}4017.96 \\
(0.000)\end{array}$ & $\begin{array}{c}99145.50 \\
(0.000)\end{array}$ & $\begin{array}{c}9468.94 \\
(0.000)\end{array}$ & $\begin{array}{c}3947.87 \\
(0.000)\end{array}$ & $\begin{array}{c}26240.81 \\
(0.000)\end{array}$ & $\begin{array}{c}448502.82 \\
(0.000)\end{array}$ & $\begin{array}{c}23019.43 \\
(0.000)\end{array}$ & $\begin{array}{c}19464.74 \\
(0.000)\end{array}$ & $\begin{array}{c}641.98 \\
(0.000)\end{array}$ & $\begin{array}{c}48047.21 \\
(0.000)\end{array}$ & $\begin{array}{c}32715.39 \\
(0.000)\end{array}$ & $\begin{array}{c}2412.23 \\
(0.000)\end{array}$ \\
\hline \multicolumn{13}{|c|}{ Diagnostic Test } \\
\hline No. of Instru.. & 20 & 21 & 21 & 38 & 20 & 21 & 21 & 38 & 20 & 21 & 21 & 38 \\
\hline No. of groups & 39 & 39 & 39 & 39 & 39 & 39 & 39 & 39 & 39 & 39 & 39 & 39 \\
\hline $\operatorname{AR}(1)$ & -1.990 & -1.810 & -1.660 & -1.760 & -2.180 & -2.040 & -2.130 & -2.070 & -1.620 & -1.610 & -1.630 & -1.580 \\
\hline $\mathrm{p}$-value & $(0.047)$ & $(0.071)$ & $(0.098)$ & $(0.079)$ & $(0.029)$ & $(0.04)$ & $(0.033)$ & $(0.039)$ & $(0.106)$ & $(0.108)$ & $(0.103)$ & $(0.114)$ \\
\hline $\operatorname{AR}(2)$ & -0.500 & -0.510 & -0.610 & -0.120 & -0.400 & -0.390 & -0.430 & -0.250 & -0.220 & -0.240 & -0.360 & 0.200 \\
\hline p-value & $(0.617)$ & $(0.608)$ & $(0.540)$ & $(0.907)$ & $(0.688)$ & $(0.699)$ & $(0.670)$ & $(0.802)$ & $(0.827)$ & $(0.807)$ & $(0.717)$ & $(0.844)$ \\
\hline Sargan Test & 12.130 & 174.460 & 24.740 & 13.720 & 9.080 & 61.130 & 12.720 & 15.550 & 22.670 & 202.280 & 188.200 & 20.810 \\
\hline p-value & $(0.792)$ & $(0.000)$ & $(0.074)$ & $(0.989)$ & $(0.938)$ & $(0.000)$ & $(0.693)$ & $(0.961)$ & $(0.160)$ & $(0.000)$ & $(0.000)$ & $(0.833)$ \\
\hline Hansen Test & 14.590 & 23.740 & 20.140 & 30.700 & 13.240 & 24.160 & 12.030 & 18.290 & 11.810 & 26.860 & 26.040 & 32.020 \\
\hline $\mathrm{p}$-value & $(0.625)$ & $(0.127)$ & $(0.214)$ & $(0.331)$ & $(0.720)$ & $(0.115)$ & $(0.742)$ & $(0.894)$ & $(0.812)$ & $(0.060)$ & $(0.053)$ & $(0.274)$ \\
\hline Wald Test & 5.030 & 4.700 & 14.900 & 20.930 & 13.260 & 8.650 & 13.520 & 7.320 & 0.070 & 6.270 & 9.170 & 17.690 \\
\hline p-value & $(0.031)$ & $(0.0150)$ & $(0.0000)$ & $(0.0000)$ & $(0.0008)$ & $(0.0008)$ & $(0.0000)$ & $(0.0000)$ & $(0.7881)$ & $(0.0044)$ & $(0.0001)$ & $(0.0000)$ \\
\hline
\end{tabular}




\subsection{Robustness Results: The Effect of Out-of-Pocket Health Expenditure and Its Interaction with Institutional Quality on Labour Force Participation}

We further examine the robustness of our results by using an alternative variable of out-of-pocket health expenditure (OPHE) rather than the domestic GHE. Table 5 presents the fixed effect regression results for the effects of OPHE and its interaction with institutional quality on LFP in Africa.

When the LFP is ran against the OPHE alone, it is observed that OPHE has positive and significant effect on female LFP only. This suggests that OPHE only encourages female LFP. In fact, when institutional quality is introduced into the model, the effect of OPHE on total and male LFP becomes negative but not significant. However, when we control for other variables, the negative effect becomes statistically significant. This suggests that OPHE discourages total and male LFP. When institutional quality is introduced into model 1, institutional quality has a negative effect on all categories of LFP. However, the introduction of interactive term changes the direction and sign of the effect of institutional quality on LFP as the effect turn positive and, in most cases, statistically significant, especially for total and female LFP. The interactive term on its own has a negative impact on LFP (total, female and male).

The effects of control variables are reported in Table 5 as well. Evidence from the Table signifies that life expectancy at birth increases as total, female and male LFP rise by $0.191 \%, 0.212 \%$ and $0.132 \%$ respectively. However, SSE leads to a decline in all categories of LFP. This is consistent with other a priori expectation that an increase in time spent in schooling would reduce LFP. This is because, during schooling, citizens that engage in schooling do not participate in the labour force. The more the categories of these people stay in school, the decline in the LFP (Burk and Montes, 2018). The TFR is found to be positively influenced by female LFP.

Table 6 reports the results of the Generalized Method of Moments (GMM) effect on OPHE and its interaction with institutional quality on LFP in Africa. The post-estimation tests show that the number of instruments does not exceed the number of groups, suggesting the validity of the instrument with the Sargen and Hansen test of overidentification. Also, the AR(2) result shows that the model does not suffer from second-order serial or autocorrelation. The Wald test was also found to be significant. The period lag of the dependent variables has been observed to have a positive and significant impact on the current LFP.

OPHE decreases total, female and male LFP by $0.024 \%, 0.023$ and $0.022 \%$ respectively. The negative effect remains unchanged when institutional quality and interactive term (Institutional quality and health expenditure) are introduced into the models. However, when control for other independent variables, OPHE increases as female LFP by $0.013 \%$. Institutional quality, when introduced, has a negative effect on all categories of all LFP. However, when control for control variables, the negative effect turns positive in all the models. The effect of interactive term on LFP is negative and significant statistically, implying poor institutional quality affects negatively the more the nexus between OPHE in African countries.

In system GMM results, LEAB, GDP growth rate and IMR decreases as total and male LFP rises. Trade openness increases with increasing total and male LFP by $0.014 \%$ and $0.022 \%$ respectively. More precisely, SSE has a 
positive and significant impact on female LFP while total fertility decreases as female LFP increases and vice versa.

The results from the OPHE do not have an improving impact on LFP. This underscores the importance of government health expenditure despite the increasing rate of overdependence on OPHE in Africa. 
Table 5: Effects of Out-of-Pocket Health Expenditure and Its Interaction with Institutional Quality on Labour Force Participation in Africa

\begin{tabular}{|c|c|c|c|c|c|c|c|c|c|c|c|c|}
\hline & \multicolumn{4}{|c|}{ Total Labour Force Participation } & \multicolumn{4}{|c|}{ Female Labour Force Participation } & \multicolumn{4}{|c|}{ Male Labour Force Participation } \\
\hline OPHE & 0.004 & -0.002 & -0.010 & $-0.024 * * *$ & $0.826^{*}$ & 0.409 & -0.003 & 0.010 & 0.003 & -0.003 & -0.006 & $-0.036 * * *$ \\
\hline & $(0.006)$ & $(0.007)$ & $(0.010)$ & $(0.007)$ & $(0.416)$ & $(0.521)$ & $(0.009)$ & $(0.009)$ & $(0.006)$ & $(0.008)$ & $(0.010)$ & $(0.008)$ \\
\hline IST & & $-0.006^{*}$ & $0.044 * * *$ & $0.047 * * *$ & & $-0.630 * *$ & $0.036 *$ & 0.004 & & -0.004 & 0.016 & $0.041 * * *$ \\
\hline & & $(0.003)$ & $(0.015)$ & $(0.012)$ & & $(0.249)$ & $(0.020)$ & $(0.025)$ & & $(0.003)$ & $(0.015)$ & $(0.010)$ \\
\hline OPHE *IST & & & - & $-0.012 * * *$ & & & $-0.012 * *$ & -0.003 & & & -0.005 & $-0.010 * * *$ \\
\hline & & & $\begin{array}{c}0.012 * * * \\
(0.004)\end{array}$ & $(0.003)$ & & & $(0.005)$ & $(0.006)$ & & & $(0.004)$ & $(0.002)$ \\
\hline GDPPCGR & & & & -0.000 & & & & -0.000 & & & & -0.000 \\
\hline & & & & $(0.000)$ & & & & $(0.000)$ & & & & $(0.000)$ \\
\hline LEAB & & & & $0.191 * * *$ & & & & $0.212 * * *$ & & & & $0.132 * * *$ \\
\hline & & & & $(0.025)$ & & & & $(0.054)$ & & & & $(0.010)$ \\
\hline SSE & & & & $-0.064 * * *$ & & & & $-0.044 * * *$ & & & & $-0.059 * * *$ \\
\hline & & & & $(0.008)$ & & & & $(0.008)$ & & & & $(0.011)$ \\
\hline IMR & & & & 0.011 & & & & -0.036 & & & & $0.037 * * *$ \\
\hline & & & & $(0.012)$ & & & & $(0.037)$ & & & & $(0.008)$ \\
\hline TFR & & & & & & & & $\begin{array}{c}0.052 * * \\
(0.020)\end{array}$ & & & & \\
\hline TOPEN & & & & $\begin{array}{l}-0.007 \\
(0.004)\end{array}$ & & & & $\begin{array}{c}-0.017 \\
(0.010)\end{array}$ & & & & $\begin{array}{l}-0.002 \\
(0.004)\end{array}$ \\
\hline Constant & $\begin{array}{c}4.158 * * \\
*\end{array}$ & $\begin{array}{c}4.174 * * \\
*\end{array}$ & $4.205^{* * *}$ & $3.703 * * *$ & $\begin{array}{c}54.258 * * \\
*\end{array}$ & $55.043 * * *$ & $3.976 * * *$ & $3.348 * * *$ & $4.300 * * *$ & $4.318 * * *$ & $4.330 * * *$ & $3.990 * * *$ \\
\hline & $(0.018)$ & $(0.022)$ & $(0.032)$ & $(0.127)$ & (1.539) & $(1.766)$ & $(0.033)$ & $(0.313)$ & $(0.018)$ & $(0.023)$ & $(0.032)$ & $(0.096)$ \\
\hline Obs. & 741 & 721 & 721 & 721 & 741 & 721 & 721 & 721 & 741 & 721 & 721 & 721 \\
\hline Within $\mathrm{R}^{2}$ & 0.0009 & 0.0060 & 0.0105 & 0.2379 & 0.0030 & 0.0091 & 0.0107 & 0.0782 & 0.0005 & 0.0029 & 0.0036 & 0.2767 \\
\hline F-statistics & 0.560 & 3.190 & $(35.49)$ & 88.810 & 5.970 & 10.470 & 9.610 & 260.760 & 0.290 & 1.270 & 12.100 & 45.950 \\
\hline & $(0.4649)$ & $(0.0653)$ & $(0.0000)$ & $(0.0000)$ & $(0.0251)$ & $(0.0010)$ & $(0.0005)$ & $(0.0000)$ & $(0.5968)$ & $(0.3037)$ & $(0.0001)$ & $(0.0000)$ \\
\hline
\end{tabular}


Table 6: Out-of-Pocket Health Expenditure and Its Interaction with Institutional Quality on Labour Force Participation in Africa

\begin{tabular}{|c|c|c|c|c|c|c|c|c|c|c|c|c|}
\hline & \multicolumn{4}{|c|}{ Total Labour Force Participation } & \multicolumn{4}{|c|}{ Female Labour Force Participation } & \multicolumn{4}{|c|}{ Male Labour Force Participation } \\
\hline Lag LFP & $\begin{array}{c}0.986 * * * \\
(0.008)\end{array}$ & $\begin{array}{c}0.992 * * * \\
(0.002)\end{array}$ & $\begin{array}{c}1.008 * * * \\
(0.009)\end{array}$ & $\begin{array}{c}1.009 * * * \\
(0.008)\end{array}$ & $\begin{array}{c}0.987 * * * \\
(0.002)\end{array}$ & $\begin{array}{c}0.991 * * * \\
(0.001)\end{array}$ & $\begin{array}{c}0.988 * * * \\
(0.001)\end{array}$ & $\begin{array}{c}1.025 * * * \\
(0.007)\end{array}$ & $\begin{array}{c}0.992 * * * \\
(0.016)\end{array}$ & $\begin{array}{c}0.989 * * * \\
(0.018)\end{array}$ & $\begin{array}{c}1.022 * * * \\
(0.011)\end{array}$ & $\begin{array}{c}1.063 * * * \\
(0.017)\end{array}$ \\
\hline OPHE & $\begin{array}{c}-0.024 * * * \\
(0.003)\end{array}$ & $\begin{array}{c}-0.004 * * * \\
(0.001)\end{array}$ & $\begin{array}{c}-0.034 * * * \\
(0.007)\end{array}$ & $\begin{array}{c}-0.009 * * * \\
(0.002)\end{array}$ & $\begin{array}{c}-0.023 * * * \\
(0.002)\end{array}$ & $\begin{array}{c}-0.005 * * * \\
(0.001)\end{array}$ & $\begin{array}{c}-0.024 * * * \\
(0.001)\end{array}$ & $\begin{array}{c}0.013 * * * \\
(0.005)\end{array}$ & $\begin{array}{c}-0.022 * * * \\
(0.006)\end{array}$ & $\begin{array}{c}-0.026 * * * \\
(0.005)\end{array}$ & $\begin{array}{c}-0.034 * * * \\
(0.006)\end{array}$ & $\begin{array}{c}-0.014 * * * \\
(0.003)\end{array}$ \\
\hline IST & & $\begin{array}{c}-0.005 * * * \\
(0.001)\end{array}$ & $\begin{array}{c}0.203 * * * \\
(0.057)\end{array}$ & $\begin{array}{c}0.046^{* * * *} \\
(0.012)\end{array}$ & & $\begin{array}{c}-0.004 * * * \\
(0.001)\end{array}$ & $\begin{array}{c}0.068 * * * \\
(0.006)\end{array}$ & $\begin{array}{c}0.009 \\
(0.022)\end{array}$ & & $\begin{array}{c}-0.005 * * * \\
(0.002)\end{array}$ & $\begin{array}{c}0.210 * * * \\
(0.042)\end{array}$ & $\begin{array}{c}0.090 * * * \\
(0.012)\end{array}$ \\
\hline GHE*IST & & & $\begin{array}{c}-0.051 * * * \\
(0.015)\end{array}$ & $\begin{array}{c}-0.012 * * * \\
(0.003)\end{array}$ & & & $\begin{array}{c}-0.019 * * * \\
(0.002)\end{array}$ & $\begin{array}{l}-0.002 \\
(0.005)\end{array}$ & & & $\begin{array}{c}-0.054 * * * \\
(0.011)\end{array}$ & $\begin{array}{c}-0.024 * * * \\
(0.003)\end{array}$ \\
\hline GDPPCGR & & & & $\begin{array}{c}-0.000 * * \\
(0.000)\end{array}$ & & & & $\begin{array}{c}0.000 * * * \\
(0.000)\end{array}$ & & & & $\begin{array}{c}-0.000 * * * \\
(0.000)\end{array}$ \\
\hline LEAB & & & & $\begin{array}{c}-0.089 * * * \\
(0.019)\end{array}$ & & & & $\begin{array}{l}-0.023 \\
(0.016)\end{array}$ & & & & $\begin{array}{c}-0.143 * * * \\
(0.024)\end{array}$ \\
\hline SSE & & & & $\begin{array}{c}-0.009 * \\
(0.005)\end{array}$ & & & & $\begin{array}{c}0.007 * * \\
(0.003)\end{array}$ & & & & $\begin{array}{c}0.009 \\
(0.006)\end{array}$ \\
\hline IMR & & & & $\begin{array}{c}-0.039 * * * \\
(0.009)\end{array}$ & & & & $\begin{array}{c}0.039 * * * \\
(0.010)\end{array}$ & & & & $\begin{array}{c}-0.041 * * * \\
(0.008)\end{array}$ \\
\hline TFR & & & & & & & & $\begin{array}{c}-0.121 * * * \\
(0.027)\end{array}$ & & & & \\
\hline TOPEN & & & & $\begin{array}{c}0.014 * * * \\
(0.004)\end{array}$ & & & & $\begin{array}{c}0.005 \\
(0.004)\end{array}$ & & & & $\begin{array}{c}0.022 * * * \\
(0.004)\end{array}$ \\
\hline _cons & $\begin{array}{c}0.142 * * * \\
(0.039)\end{array}$ & $\begin{array}{c}0.039 * * * \\
(0.008)\end{array}$ & $\begin{array}{c}0.094 * * \\
(0.045)\end{array}$ & $\begin{array}{c}0.488 * * * \\
(0.109)\end{array}$ & $\begin{array}{c}0.138 * * * \\
(0.014)\end{array}$ & $\begin{array}{c}0.054 * * * \\
(0.005)\end{array}$ & $\begin{array}{c}0.135 * * * \\
(0.004)\end{array}$ & $\begin{array}{l}-0.063 \\
(0.063)\end{array}$ & $\begin{array}{c}0.110 \\
(0.072)\end{array}$ & $\begin{array}{l}0.134 * \\
(0.079)\end{array}$ & $\begin{array}{c}0.033 \\
(0.042)\end{array}$ & $\begin{array}{c}0.402 * * * \\
(0.135)\end{array}$ \\
\hline Obs. & 702 & 683 & 683 & 683 & 702 & 683 & 683 & 683 & 702 & 683 & 683 & 683 \\
\hline F-statistics & $\begin{array}{c}8742.57 \\
(0.000)\end{array}$ & $\begin{array}{c}100378.90 \\
(0.000)\end{array}$ & $\begin{array}{c}3582.21 \\
(0.000)\end{array}$ & $\begin{array}{c}9197.36 \\
(0.000)\end{array}$ & $\begin{array}{c}89806.00 \\
(0.000)\end{array}$ & $\begin{array}{c}333778.44 \\
(0.000)\end{array}$ & $\begin{array}{c}2.09 e+06 \\
(0.000)\end{array}$ & $\begin{array}{c}47500.14 \\
(0.000)\end{array}$ & $\begin{array}{c}1871.18 \\
(0.000)\end{array}$ & $\begin{array}{c}1022.04 \\
(0.000)\end{array}$ & $\begin{array}{c}3304.50 \\
(0.000)\end{array}$ & $\begin{array}{c}39480.76 \\
(0.000)\end{array}$ \\
\hline \multicolumn{13}{|c|}{ Diagnostic Test } \\
\hline No. of Instru.. & 20 & 21 & 21 & 38 & 20 & 21 & 38 & 38 & 20 & 21 & 21 & 38 \\
\hline No. of groups & 39 & 39 & 39 & 39 & 39 & 39 & 39 & 39 & 39 & 39 & 39 & 39 \\
\hline $\operatorname{AR}(1)$ & -1.790 & -1.800 & -2.130 & -1.910 & -2.030 & -2.040 & -2.060 & -2.070 & -1.590 & -1.610 & -2.070 & -2.020 \\
\hline $\mathrm{p}$-value & $(0.074)$ & $(0.072)$ & $(0.033)$ & $(0.056)$ & $(0.042)$ & $(0.042)$ & $(0.040)$ & $(0.038)$ & $(0.112)$ & $(0.106)$ & $(0.039)$ & $(0.044)$ \\
\hline $\mathrm{AR}(2)$ & -0.480 & -0.500 & -0.090 & -0.320 & -0.330 & -0.400 & -0.400 & -0.240 & -0.310 & -0.220 & 0.060 & 0.300 \\
\hline $\mathrm{p}$-value & $(0.632)$ & $(0.619)$ & $(0.931)$ & $(0.747)$ & $(0.742)$ & $(0.687)$ & $(0.687)$ & $(0.812)$ & $(0.755)$ & $(0.823)$ & $(0.949)$ & $(0.767)$ \\
\hline Sargan Test & 51.360 & 148.580 & 21.730 & 24.320 & 28.760 & 57.350 & 56.610 & 23.680 & 78.870 & 52.524 & 52.460 & 22.780 \\
\hline p-value & $(0.000)$ & $(0.000)$ & $(0.152)$ & $(0.664)$ & $(0.037)$ & $(0.000)$ & $(0.006)$ & $(0.648)$ & $(0.000)$ & $(0.000)$ & $(0.000)$ & $(0.744)$ \\
\hline Hansen Test & 20.970 & 23.090 & 14.720 & 21.32 & 18.080 & 25.130 & 37.930 & 30.210 & 23.900 & 20.560 & 16.840 & 27.800 \\
\hline p-value & $(0.227)$ & $(0.146)$ & $(0.545)$ & $(0.812)$ & $(0.384)$ & $(0.092)$ & $(0.255$ & $(0.305)$ & $(0.122)$ & $(0.196)$ & $(0.396)$ & $(0.475)$ \\
\hline Wald Test & 51.570 & 15.820 & 16.850 & 11.970 & 86.250 & 18.900 & 55.470 & 9.710 & 11.840 & 15.170 & 123.72 & 22.940 \\
\hline p-value & $(0.0000)$ & $(0.0000)$ & $(0.0000)$ & $(0.0000)$ & $(0.0000)$ & $(0.0000)$ & $(0.0000)$ & $(0.0000)$ & $(0.0014)$ & $(0.0000)$ & $(0.0000)$ & $(0.0000)$ \\
\hline
\end{tabular}

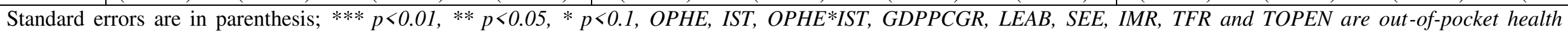

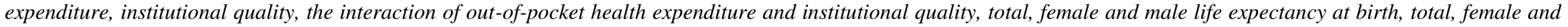
male secondary school enrolment, total, female and male infant mortality rate, total fertility rate and trade openness respectively. 


\subsection{Conclusion and Policy Implications}

In this study, we have examined the effect of institutional role in health expenditure and labour force participation in 39 African countries over the period 2000 and 2018. We consider the impact of government health expenditure visà-vis out-of-pocket health expenditure on different categories of labour force participation, particularly total, female and labour force participation. Aside from this, we take into cognise what the role of quality of institutions in Africa has to play in the relationship between health expenditure and labour force participation. In order to implement our objectives, we employ two specific estimation techniques, namely: Panel Fixed Effects estimation method that accounts for Driscoll and Kraay (1998) standard errors and two-stage system GMM. While accounting for Driscoll and Kraay (1998) standard errors allow Fixed Effects estimation to address the issue of heteroscedasticity and autocorrelation method, the system GMM addresses the issue of endogeneity characterising the modelling of nexus between health expenditure and labour force participation.

Interesting findings are found from our study. The supremacy of government health expenditure over out-of-pocket health expenditure in spurring all categories of labour force participation is documented in all the estimation techniques employed. This underscores the indispensability of the government's investment in the health sector. Our findings can be explained from two perspectives. Governments have the capability in terms of resources to invest in health infrastructure or equipment that would improve the health status of the citizens that would enable them to participate in the labour force. This is because only healthy citizens can actively participate in the labour force. Second, the majority of the citizens in developing countries are poor even though out-of-health expenditure is on the increase. Hence, they only seek health services when the crucial need arises. In fact, the majority of the citizens in poor countries like many African countries seek health services when it is almost too late. Consequently, their health expenditure may not spur their participation in the labour force as expected.

We also document that the poor quality of institutions in Africa is detrimental to labour force participations either total, female or male labour force participation. This is not surprising considering the low level of institutional quality in many countries that make up the continent. Corruption is still rampant in many African countries, even among the strong and resources endowed countries. Rule of law and protection of human rights and properties are still mirage in many African countries despite many years of democratic system of government. The transition from one government to another is still marred with violence that results in political instability. The existence of corruption and political instability in any country has a high tendency to discourage labour force participation. The appalling low institutional quality is manifested in the relationship between health expenditure and labour force participation. Specifically, we find that institutional quality moderated downwards the positive nexus between government health expenditure and all categories of labour force participation, suggesting that poor quality of institutions worsens the nexus between government health expenditure and labour force participation.

Although the effects of control variables such as GDP per capita growth rate, life expectancy at birth (total, female and male), gross secondary school enrolment (total, female and female), infant mortality rate (total, female and male), total fertility rate and trade openness on labour force participation varies across models, albeit we can affirm 
that GPD per capita growth rate does not have any discernible impact on labour force participation. Life expectancy at birth positively influences labour force participation. However, secondary school enrolment reduces labour force participation. Infant mortality rate positively affects labour force participation while total fertility rate has a positive effect on labour force participation. However, trade openness is only detrimental to female labour force participation.

Two policy implications can be drawn from our findings. First, there is a need to increase health expenditure, particularly government health expenditure so as to spur labour force participation in the continent of Africa. Also, institutional quality in the continent needs to be improved to ensure that health expenditure is properly spent without being misappropriated by some groups of people.

\section{Declaration}

Funding: No funding is available

Conflict of Interest/Competing Interests: No conflict of interest among the authors

Availability of data and material: Data is available

Code Availability: Code is available

Authors' Contributions

OSO wrote introduction, literature review, discussion of stylised facts

TOF: Discussed the estimated results

IAR: Conceptualisation of Idea, Data Curation, Methodology and Estimation.

Ethical Approval: Not Applicable

Consent to participate: All authors agree to participate

Consent to publication: All authors agree to publish the article 


\section{References}

Acemoglu, D (2010) Growth and institutions.in Economic Growth (pp. 107-115).Palgrave Macmillan, London.

Acemoglu, D, Robinson, J. (2008) The role of institutions in growth and development (Vol.10). Washington DC: World Bank.

Acemoglu, D, Johnson, S, Robinson, JA (2005) Institutions as a fundamental cause of long-run growth. Handbook of economic growth, 1, 385-472.

Agovino, M, Garofalo, A, Cerciello, M (2019) Do local institutions affect labour market participation? The Italian case. The BE Journal of Economic Analysis \& Policy, 19(2).

Ahn, N, Mira, P (2002) A note on the changing relationship between fertility and female employment rates in developed countries. Journal of Population Economics, 15(4), 667-682.

Alagidede, IP, Ibrahim, M, and Sare, YA (2020) Structural transformation in the presence of trade and financial integration in sub-Saharan Africa. Central Bank Review (CBR), 20(1), 21-31.

Al-Jebory, JMH (2014) Effects of Health Expenditures on Population Age Distribution and Labor Force Participation Rates: Empirical and Comparative Analysis. Master's Theses. 516. http://scholarworks.wmich.edu/masters_theses/516

Aluko, OA, Ibrahim, M (2020) Institutions and financial development in ECOWAS. Journal of Sustainable Finance \& Investment, Vol. 11, Issue 2, pp. 1-12.

Anochiwa, LI, Obila, E, Enyoghasim, M (2019) Modeling the effects of health care expenditure and economic growth in Nigeria: An econometric analysis. Jurnal Perspektif Pembiayaan dan Pembangunan Daerah, 6(5), 573-582.

Arellano, M, Bover, O (1995) Another look at the instrumental variable estimation of error components models. Journal of Econometrics, 68(1), 29-51.

Ayanwu JC, Erhijakpor AE (2007) Health Expenditures and Health Outcomes in Africa. African Development Bank; Economic Research Working Paper Series.

Barro, RJ (1991) Economic growth in a cross-section of countries.Quarterly Journal Econ.Vol 106 (2): pp. $407-443$

Becker, G (1964) Human Capital: Theoretical and Empirical Analysis. University of Chicago Press.

Becker, GS (1962) Investment in human capital: A theoretical analysis. Journal of political economy, 70(5, Part 2), 9-49.

Becker, GS (2009) Human capital: A theoretical and empirical analysis, with special reference to education. University of Chicago Press.

Blundell, R, Bond, S (1998). Initial conditions and moment restrictions in dynamic panel data models. Journal of Econometrics, 87(1), 115-143.

Boachie, MK, Ramu, K (2015) Public Health Expenditure and Health Status in Ghana. Online at https://mpra.ub.uni-muenchen.de/66371/ MPRA Paper No. 66371

Bousmah, M,Ventelou B, Abu-Zaineh M (2016) Medicines and democracy: The importance of institutional quality in the relationship between health expenditure and health outcomes in the MENA region. Applied Health, Equity and Development Research Network (AHEAD). Working Paper No. 01/2016 
Bowen, WG, Finegan, TA (1969) The economics of labour force participation. Princeton University Press.

Burk, DM, Montes, J (2018) Factors Affecting the Labor Force Participation of People Ages 25-54. Congress of the United States, Congressional Budget Office.

Cai, L (2010) The relationship between health and labour force participation: Evidence from a panel data simultaneous equation model. Labour Economics, 17(1), 77-90.

Cai, L, Kalb, G (2006) Health status and labour force participation: evidence from Australia. Health economics, 15(3), 241-261.

Cooray, A, Dzhumashev, R (2018) The effect of corruption on labour market outcomes. Economic Modelling, 74, 207-218.

Devarajan, S, Swaroop, V, Zou, HF (1996) The composition of public expenditure and economic growth. Journal of monetary economics, 37(2), 313-344.

Dhrifi A (2020) Public Health Expenditure and Child Mortality: Does Institutional Quality Matter? Journal of Knowledge Economy, Vol 11:692-706. https://doi.org/10.1007/s13132-018-0567-4

Driscoll, JC, Kraay, AC (1998) Consistent covariance matrix estimation with spatially dependent panel data. Review of economics and statistics, 80(4), 549-560.

Hoechle, D (2007) Robust standard errors for panel regressions with cross-sectional dependence. The stata journal, 7(3), 281-312.

Farag, M, Nandakumar, AK, Wallack, S, Hodgkin, D, Gaumer, G, Erbil, C (2013) Health expenditures, health outcomes and the role of good governance. International journal of health care finance and economics, 13(1), 33-52.

Grossman, M (1972) On the Concept of Health Capital and the Demand for Health. The Journal of Political Economy, 80(2), 223-255.

Ibrahim, M, Vo, XV (2020) Effect of economic integration on sectorial value added in sub-saharan Africa: Does financial development matter?. The Journal of International Trade \& Economic Development, 29(8), 934951.

International Labour Organisation (2018). World Employment and Social Outlook: Trends 2018 (Geneva)

Iregui-Bohórquez, AM, Melo-Becerra, LA, Ramírez-Giraldo, MT (2016) Health status and labor force participation: evidence for urban low and middle income individuals in Colombia. Portuguese Economic Journal, 15(1), 33-55.

Isiaka AM (2020) How does Government Spending affect Labour Force Participation and Unemployment within the WAMZ countries?International Journal of Social Science Research, Vol 8 (2), URL: http://dx.doi.org/10.5296/ijssr.v8i2.16412

Juhn, C, Ureta, M (2003) Employment of married women and economic development: evidence from Latin American countries. In Society of Labor Economists Meeting, Toronto.

Laplagne, P, Glover, M, Shomos, A (2007) Effects of Health and Education on Labour Force Participation (No. 0704). Productivity Commission, Government of Australia. 
Lechman, E (2014) Female labor force participation and economic growth-re-examination of U-shaped curve (No. 21). Faculty of Management and Economics, Gdansk University of Technology.

Makuta I, O'Hare, B (2015) Quality of governance, public spending on health and health status in Sub Saharan Africa panel data regression analysis. BMC Public Health, 15:932. DOI 10.1186/s12889-015-2287

Massimiliano, A, Antonio, G. and Massimiliano C. (2019). Do Institutions Affect Labour Market Participation? The Italian case. The B.E. Journal of Economic Analysis and policy, De Gruyter, 19(2):1-21.

Mushtaq, A, Mohsin A, Zaman, K (2013) Effects of health on changing labor force participation in Pakistan. SpringerPlus, Vol 2:610. doi:10.1186/2193-1801-2-610.

Mustafa, ME, Ebaidalla EM, Kamel, RR (2020) Foreign Aid and Out-of-Pocket Health Expenditure in SSA Countries: Does Institutional Development Matter? International journal of sustainable economy, inderscience enterprises Ltd, 12(3), 259-280

Novignon, J, Nonvignon, J, Arthur, E (2015) Health Status and Labour Force Participation in Sub-Saharan Africa: A Dynamic Panel Data Analysis. African Development Review 27 (1): 14-26.

Novignon J (2015) On the efficiency of public health expenditure in Sub-Saharan Africa: Does corruption and quality of public institutions matter? MPRA Paper, No. 39195. Online at https://mpra.ub.unimuenchen.de/39195/

Osundina, OA (2020) Sustainable development: Does improvement in education and health of women improve female labour force participation rate?. Sustainable Development, 28(1), 13-24.

Piabuo SM, Tieguhong CT (2017) Health expenditure and economic growth a review of the literature and an analysis between the economic community for central African States (CEMAC) and selected African countries. Health Economics Review, Vol 7:23. DOI 10.1186/s13561-017-0159-1.

Powell, D, Seabury, S (2018) Medical care spending and labor market outcomes: Evidence from workers' compensation reforms. American Economic Review, 108(10), 2995-3027.

Raifu, I A, Nnadozie, OO, Adeniyi, OA (2021). Infrastructure-Structural Transformation Nexus in Africa: The Role of Financial Sector Development. Journal of African Development, Vol. 22 Issue 1, pp. 122-163

Rauf, A, Bashir, M, Asif, K, Saleem, SF (2018) Impact of Health Expenditures on Labor Force Participation: Evidence from Pakistan. Asian Journal of Economic Modelling, 6(4), 419-427.

Rizvi, S. A. F. (2019). Health Expenditures, Institutional Quality and Economic Growth. Empirical Economic Review, 2(1), 63-82.

Romer, PM (1990) Endogenous Technological Change. Journal Of Political Economy, 98 (5, Part 2), S71-S102.

Roodman, D (2009a) How to do xtabond2: An introduction to difference and system GMM in Stata. The Stata Journal, 9(1), 86-136.

Roodman, D (2009b) A note on the theme of too many instruments. Oxford Bulletin of Economics and Statistics, 71(1), 135-158.

Stern, S (1989) Measuring the effect of disability on labour force participation. Journal of Human Resources, 361395. 
Su, TT, Pokhrel, S, Gbangou, A, Flessa, S (2006) Determinants of household health expenditure on western institutional health care. The European Journal of Health Economics, 7(3), 195-203.

Thu Ha, N (2018) The relationship between GDP, labor force and health expenditure in European countries. Econometrics-Term paper.

Umoru D, Yaqub JO (2015) Labour Productivity and Health Capital in Nigeria: The Empirical Evidence. International Journal of Humanities and Social Science, 3(4):199-221.

Waghorn, G, Lloyd, C (2005) The employment of people with mental illness. Australian e-journal for the Advancement of Mental Health, 4(2), 129-171. 


\section{Supplementary Files}

This is a list of supplementary files associated with this preprint. Click to download.

- dataandcodes.zip 